Florida International University FIU Digital Commons

4-6-2001

\title{
Diet as a measure of acculturation in diabetic and non diabetic Cuban Americans
}

Frances Dianne Asencio

Florida International University

DOI: $10.25148 /$ etd.FI14032354

Follow this and additional works at: https://digitalcommons.fiu.edu/etd

Part of the Dietetics and Clinical Nutrition Commons

\section{Recommended Citation}

Asencio, Frances Dianne, "Diet as a measure of acculturation in diabetic and non diabetic Cuban Americans" (2001). FIU Electronic

Theses and Dissertations. 1319.

https://digitalcommons.fiu.edu/etd/1319

This work is brought to you for free and open access by the University Graduate School at FIU Digital Commons. It has been accepted for inclusion in FIU Electronic Theses and Dissertations by an authorized administrator of FIU Digital Commons. For more information, please contact dcc@fiu.edu. 


\title{
FLORIDA INTERNATIONAL UNIVERSITY
}

\author{
Miami, Florida
}

\section{DIET AS A MEASURE OF ACCULTURATION IN DIABETIC AND NON DIABETIC CUBAN AMERICANS}

\author{
A thesis submitted in partial fulfillment of the \\ requirements for the degree of
}

MASTER OF SCIENCE

in

DIETETICS AND NUTRITION

By

Frances Dianne Asencio

2001 
To: Dean Ronald M. Berkman

College of Health and Urban Affairs

This thesis, written by Frances Dianne Asencio, and entitled Diet as a Measure of Acculturation in Diabetic and Non-diabetic Cuban Americans, having been approved in respect to style and intellectual content, is referred to you for judgment.

We have read this thesis and recommended that it be approved.

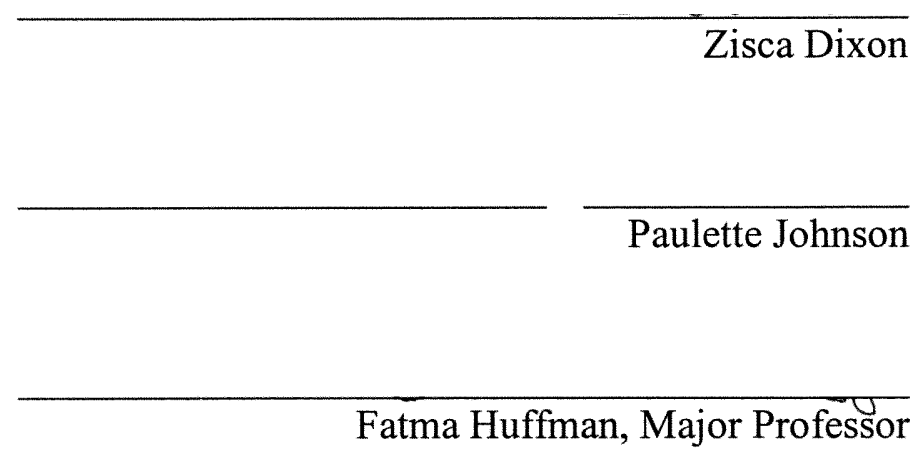

Date of the Defense: April 6, 2001

The thesis of Frances Dianne Asencio is approved.

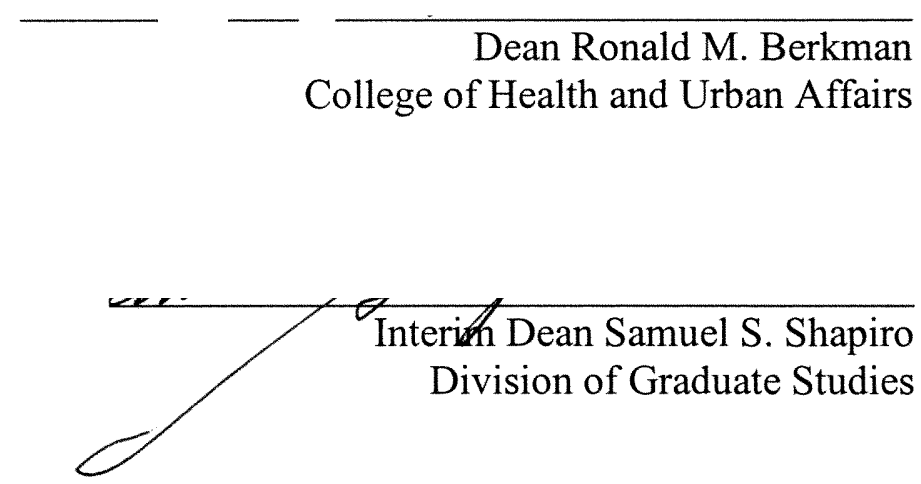

Florida International University, 2001 


\section{DEDICATION}

I dedicate this thesis to my friend Mr. Subrata Nath. Through his friendship and support, he made the completion of this work possible. I value his friendship, patience and understanding. 


\section{ACKNOWLEDGMENTS}

I wish to thank the members of my committee for their patience, hard work and dedication. Their guidance has been greatly appreciated. Dr. Fatma Huffman, my advisor, has been especially diligent and consistent in her efforts to guide me in the right direction. Furthermore, Dr. Huffman has given me strength throughout the completion of this work, and has never doubted my abilities. I would also like to thank Dr. Zisca Dixon, who continued to advise me and provide useful information for the completion of my work. I would also like to thank Dr. Paulette Johnson for taking the time to assist me in analyzing and interpreting the data. Also, I would like to thank Mr. Guillermo Wated and Ms. Shirley Deleón, RD, LD for their input and positive influence. 


\section{ABSTRACT OF THE THESIS \\ DIET AS A MEASURE OF ACCULTURATION IN DIABETIC AND NON- DIABETIC CUBAN AMERICANS}

by

Frances Dianne Asencio

Florida International University, 2001

Miami, Florida

Professor Fatma G. Huffman, Major Professor

The purpose of this study was to establish baseline information on the way in which acculturation affects Cuban Americans' dietary habits. In addition, the study explored differences in post-migration food preference between diabetic and non-diabetic Cuban Americans. The study was a cross-sectional survey utilizing a convenient sample of Cuban Americans living in Miami-Dade County. One hundred seventy-eight first generation Cuban Americans completed the Multidimensional Acculturation Survey for Cuban Americans (MAS-CA) which included a Dietary Bidimensional Acculturation Scale (D-BAS). Food acculturation scores for Cuban and American food choices were calculated from the D-BAS. Overall, the mean Cuban food score (CFS) $(31.8 \pm 9.4)$ was significantly higher $(\mathrm{P}<0.001)$ than the mean American food score (AFS) $(15.7 \pm 8.6)$. The Cuban Americans who participated this study preferred Cuban foods to American foods. Moreover, the higher the level of acculturation, the smaller the difference between the CFS and the AFS. There was a statistically significant $(\mathrm{P}<0.001)$ negative relationship between the CFS and the acculturation score. Lower acculturation language 
scores were associated with higher CFS. Regardless of the presence of diabetes, Cuban Americans preferred Cuban foods. Having type 2 diabetes negatively influenced the subjects' alcohol consumption. It was demonstrated that the instrument developed for this study (D-BAS) was able to measure the subject's dietary acculturation. This instrument can be used as a measure of acculturation, either singularly or in a combination with other measures. In designing nutrition intervention programs, it may be necessary to determine food acculturation levels in order to have more effective programs. 


\section{TABLE OF CONTENTS}

CHAPTER

I. INTRODUCTION.

II. REVIEW OF LITERATURE ..................................... 6

What is Acculturation?......................................... 6

How Acculturation Has Been Measured in Hispanic Populations........ 9

Shortcomings of the Methods That Have Been Used.................... 13

Dietary Acculturation, How is it Measured?........................... 14

Why Measure Acculturation?.................................. 17

How Does Post-Migration Dietary Changes Affect the Rest of the Acculturation Process?............................................... 18

Acculturation Effect on Diet, Disease, Health, and Alcohol............. 19

III. PURPOSE OF THE RESEARCH................................ 25

Objectives................................................ 26

Hypotheses.................................................. 26

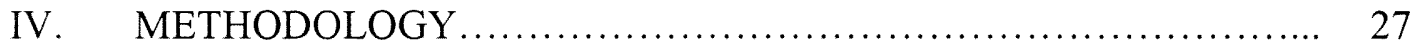

Study Design ................................................ 27

Subjects................................................. 27

Inclusion/Exclusion Criteria for the Selection of Subjects............. 27

Instrument/Multidimensional Acculturation Survey................... 28

Data Collection............................................... 31

Statistical Analysis.............................................. 31

V. RESULTS ................................................ 33

Dietary Pattern and Acculturation............................... 37

Alcohol Consumption......................................... 45

Length of Stay, Acculturation, and Diet.......................... 49

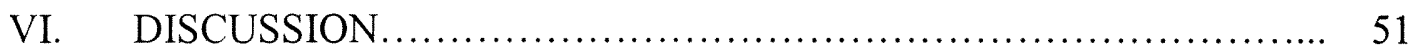

Sample Collection............................................ 52

Limitations................................................... 57

Conclusion................................................... 58

Recommendation for Future Research............................ 58

VII. REFERENCES................................................. 60

VIII. APPENDICES ................................................. 65 


\section{LIST OF TABLES}

TABLE

PAGE

I. Diabetes Status of the Subjects................................. 34

II. Demographic and Socioeconomic Characteristics of the Subjects...... 35

III. Preference of Language Usage by the Subjects..................... 36

IV. Alcohol Consumption Among Subjects Who Drink .................. 38

V. Top Food Items Consumed Most Frequently by Selected Cuban Americans in Miami................................................... 39

VI. Comparison of Acculturation Scores with the CFS and the AFS........ 44

VII. Comparison of Cuban and American Food Scores for NIDDM and Non-diabetics....

VIII. Comparison of Acculturation Scores and diet by Length of Stay in the

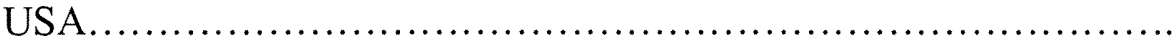




\section{Introduction}

Hispanic Americans are the second-fastest growing and largest minority group living in the United States (Chávez, Sha, Pesky, Langenberg, and Pestano-Binghay, 1994). In 1993, Hispanics represented ten percent or 27 million of the United States population (National Institute of Health, National Institute of Health and Kidney Disease, 1997). It is expected that by the year 2050, Hispanics will constitute $21 \%$ of the United States population, while other researchers stated that they will become the largest minority group in the United States (Aldrich \& Variyam, 2000; Council of Scientific Affairs, 1991; National Institute of Health, National Institute of Health and Kidney Disease, 1995; Negy \& Woods, 1992; Pawson, Martorell, and Mendoza, 1991).

Diabetes mellitus is a syndrome that comprises a heterogeneous group of disorders characterized by hyperglycemia resulting from absolute or relative impairment in insulin secretion and / or insulin action (National Institute of Health, National Institute of Health and Kidney Disease, 1995). Non-insulin dependent diabetes mellitus (NIDDM) and insulin dependent diabetes mellitus (IDDM) are the two major types of diabetes followed by gestational diabetes and diabetes secondary to other conditions. It is well documented in the literature that the prevalence of NIDDM is two to three times higher in Hispanic Americans than non-Hispanic Whites or White Americans (Council of Scientific Affairs, 1991; Flegal et al., 1991; Garza, 1995; National Institute of Health, National Institute of Health and Kidney Disease, 1995; National Institute of Health, National Institute of Health and Kidney Disease, 1997). In contrast, the incidence of IDDM is lower among Hispanic Americans when compared with non-Hispanic Whites. 
Diabetes in Hispanic Americans is a serious health challenge considering the high prevalence, greater incidence of diabetes complication, and the greater number of risk factors among this minority group (National Institute of Health, National Institute of Health and Kidney Disease, 1997). Also, Diabetes mellitus, especially NIDDM, has been identified as a major cause of morbidity and mortality among the largest Hispanic American group, Mexican Americans (Flegal et al., 1991). In 1993, there were about 1.8 million Hispanic American adults between the ages of 20 to 74 years who had diabetes (National Institute of Health, National Institute of Health and Kidney Disease).

Mexican-Americans represent the largest Hispanic American subgroup (64\%), followed by Central and South Americans (13.4\%), and Puerto Ricans, who represent $10.5 \%$ of the total Hispanic American population (National Institute of Health, National Institute of Health and Kidney Disease). Cuban Americans represent the fourth largest Hispanic American subgroup (4.7 percent) (National Institute of Health, National Institute of Health and Kidney Disease, 1997). Although the prevalence of diabetes among Cuban Americans is lower than that of other Hispanic subgroups, it is still higher than that of White Americans (National Institute of Health, National Institute of Health and Kidney Disease, 1997).

Among the major diabetes complications are kidney, eye, nerve, heart, and peripheral vascular diseases, with heart disease being the most common cause of death in people with NIDDM. It is well recognized in the literature that diet, for example reducing dietary fats and cholesterol, plays an important role in the onset and complications of chronic diseases, such as diabetes and coronary heart disease (Aldrich \&Variyam, 2000; F \& NB, CLS/NRC, 1989; Frazao, 1996; Moreno, 1997). Other health 
conditions in which diet plays an important role include cancer, obesity, osteoporosis, hypertension, and neural tube defects (Aldrich \& Variyam; F \& NB, CLS/NRC; Frazao; Moreno).

It is estimated that these health conditions cost society approximately $\$ 250$ billion per year in medical charges and loss of productivity (F \& NB, CLS/NRC, 1989; Frazao, 1996). It is still a question of the magnitude to which these conditions might be reduced by a healthy diet. However, some research estimates that a proper diet might decrease the risk of coronary heart disease by at least $20 \%$ (F \& NB, CLS/NRC). Others have stated that a healthy diet may prevent at least $20 \%$ of the annual deaths from diabetes, cancer, strokes, and heart disease (Frazao).

There is little information available on the dietary practices of Cuban Americans. Moreover, there is a need for a better understanding of the influence of acculturation on dietary patterns (Bermúdez, Falcón, and Tucker, 2000; Lee, Sobal, \& Frongillo, 999b). The latter has been vaguely discussed in the literature. In fact, no study has measured acculturation through changes in the dietary pattern of Cuban immigrants. Instead, language preference has been the preferred variable to measure acculturation (Barona \& Miller, 1994; Gardner, Winkleby, \& Vitery 1995; Gómez 1990; Khan, Sobal, \& Martotrell, 1997; Marín \& Gamba, 1996; Negy \& Woods, 1992; Pawson et al., 1991; Solis, Marks, Garcia, Shelton, 1990).

It is well documented in the literature that there is a need for studies of Hispanics to investigate nutrient intakes, as well as other aspects of dietary behavior (Chávez et al., 1994; Gardner et al., 1995; Lee et al., 1999b; Marín \& Gamba, 1996; Romero-Gwynn et al., 1993). Currently, there is little information or data on the 
available qualitative aspects of Cuban American dietary patterns. Consumption of traditional and non-traditional Cuban foods, changes in dietary practices after migrating to the United States and associations of dietary practices with level of acculturation are not clear. In a new cultural environment the food intake and the dietary patterns are affected, but the progression of these changes is dependent on many factors such as the socioeconomic status, education, eating environment, period of time after migration, health consciousness, food availability and quality among others factors (Lee et al.). The effects of migration and acculturation on dietary patterns and disease risk have important implications for health professionals, especially when it is known that the prevalence of diet related to chronic diseases differ between Hispanics and non-Hispanic Whites.

Unfortunately, many researchers clump Hispanics together as a homogenous group of people who share a Spanish-language heritage (Hajat, Lucas, \& Kington, 2000; Lang, 1992; Moreno, 1997). However, Hispanics are a diverse collection of cultural subgroups. Each subgroup of Hispanics has its own traditional diet with positive and negative components. The dietary patterns of immigrants may be compounded, or may have changed after their move to the United States. This change may be influenced by the American food pattern, advertisements in magazines, on television, in newspapers, and the media in general as well as other factors such as socioeconomic status. On the other hand, most of the information available on Hispanic health and food pattern comes from four major studies: the Starr County Study (Hanis et al., 1983), the Hispanic Health and Nutrition Examination Survey (HHANES, 1982-84; Flegal et al., 1991), the San Antonio Heart Study (Stern, Gaskill, Hazuda, Gardner, \& Haffner, 1983), and the San Luis Valley Diabetes Study (Hamman et al., 1989), which were done with Mexican 
Americans. Only one of the above-mentioned studies, HHANES, included Cuban Americans. Therefore, most of the generalizations made with respect to Hispanic Americans dietary pattern (regardless of the national origin) were based on Mexican Americans. Insufficient information is available on Cuban Americans and their dietary habits prior and post migration.

Researchers have attempted to study the relationship between diet and acculturation (Bermúdez et al., 2000; Gardener et al., 1995; Glanz \& Kolonel, 1998; Lee et al., 1999a; Lee et al., 1999b; Romero-Gwynn et al., 1993; Satia et al., 2000). However, among the common problems encountered in the acculturation scales used in the studies was the fact that researchers rarely measured various areas of acculturative changes (Bermúdez et al.; Cortéz \& Rogler, 1994; Gutmann, 1999; Lee et al., 1999b; Marín, Posner, \& Kinyon, 1993; Negy \& Woods, 1992). A significant problem was the fact that researchers have utilized items that were previously assumed to measure the complex concept of acculturation such as language use, preference, and length of stay in the United States (Marín \& Gamba, 1996). Moreover, the meaning of acculturation has been poorly defined in most of the studies that attempted to explore acculturation among immigrants of the United States (Gutmann). Therefore, a study that attempts to explore the relationship of dietary changes and acculturation among one of the largest minority groups in the United States, Cuban Americans, will be very useful for other researchers who desire to investigate the relationships of Cuban American dietary patterns, health, and diseases. 


\section{What is Acculturation?}

The term "acculturation" has been widely used in the literature, however it means different things to different people (Gutmann, 1999). The lack of agreement among researchers on an operational definition or meaning and an assessment device for acculturation have led to adverse conclusions and erroneous classification of people into clusters (Negy \& Woods, 1992; and Lee, 1999b). The term is generally used to describe the process by which one cultural group adopts the customs, beliefs, and practices of another culture through prolonged and continuous interaction between their different sociocultural systems (Gutmann; Schltz, Spindler, \& Josephson, 1994). It is also commonly referred as the transfer of culture from one group of people to another. More specifically, it can be defined as a process of change experienced by members of a minority group towards the adoption of the customs of a majority group (Negy \& Woods). The opposite has been rarely discussed. This unidirectional phenomenon fails to recognize the influence of Hispanic culture on American culture (Negy \& Woods). A good example of this can be seen in Miami-Dade County where most of the Cuban Americans live. In the 1980 s, more than 400 Cuban restaurants and approximately 700 Cuban grocery stores were found in the Miami area (Sanjur, 1995). Currently, most of the fast food establishments include in their menus Hispanic food items such as rice, beans and the famous Cuban coffee. Besides restaurants and food, the Spanish language has a tremendous influence in this part of the USA. Despite an ordinance that was passed in 1973 to make Miami-Dade County bilingual, a new legislature (1980) passed an anti- 
bilingual ordinance (Sanjur). However, the media (the radio, newspapers, television, and magazines) have continuously encouraged the use of the Spanish language. Therefore, the impact of a minority group over the majority group cannot be ignored when discussing acculturation.

Although these definitions provide different aspects of acculturation such as adoption and interaction of cultures, customs, beliefs, and critique of the unidirectional phenomenon, they are not clear enough to include the complex meaning of acculturation. Instead, acculturation can be defined as a long-term and continuous process in which individuals concurrently move along at least two main cultures to learn and/or to modify some aspects of the new culture while maintaining the original culture (Marín \& Gamba, 1996). Acculturation outcomes result from a wide range of experiences which target feelings and beliefs that have been described as a diversity of adaptation representing disconnection, marginalization, coherence or biculturality, and finally, assimilation in terms of cultural identification with other groups (Dana, 1996). Proponents of this multicultural approach point out that acculturation is a two-dimensional process in which the acquisition of the new culture is not necessarily accompanied by abandonment of the culture of origin (Sánchez \& Fernández, 1993).

Biculturalism is commonly defined as the process by which members of an ethnic group living within a dominant culture not only assimilate the larger culture, but also, simultaneously maintain their own roots (Gómez, 1990). However, assimilation by itself, which goes well with the monocultural approach, promotes the breaking of sociocognitive links with one's own culture as a way to merge into the mainstream (Sánchez \& Fernández, 1993). A monocultural approach is defined as the 
operationalization of ethnic identification as an all or none categorization, or it may be represented by either one of the two extremes of a continuum of acculturation (Sánchez \& Fernández; Gómez). This approach is being criticized because it ignores that members of different ethnic minorities may present a different range of immersion into their own and into the new culture (Sánchez and Fernández).

Biculturality is more associated with good psychological well-being than monoculturalism (Gómez, 1990). It is now assumed that in order to be well adjusted, immigrants must not only accept the presence and influence of the new culture, but simultaneously maintain their own traditional beliefs and customs (Gómez). Birman (1998) suggests that biculturalism is the most advantageous style of acculturation because it allows personal flexibility to be drawn upon different sets of skills depending on different situations. Monoculturalism can be represented by either one of the two extremes of a continuum of acculturation, where biculturalism is encountered at the middle range of the continuum (Gómez).

A positive ethnic identification, as well as feelings of belonging and understanding to the host culture, results in superior psychological functioning among immigrants (Gómez, 1990). Positive feedback from members of the mainstream culture is essential for biculturalism to occur (Gómez). Therefore, in view of the high volume of Hispanic immigrants in the United States, biculturalism should be encouraged in order to prevent mental and physical health problems such as alcohol abuse (Gómez). 
How Acculturation Has Been Measured in Hispanic Populations

Language has been the preferred indicator of an individual's overall acculturation level followed by generation level or length of stay in the United States (Barona \& Miller, 1994; Gardner et al., 1995; Gómez, 1990; Khan et al., 1997; Lee et al., 1999a; Marín \& Gamba, 1996; Negy \& Woods, 1992; Pawson et al., 1991; Solis et al., 1990). Knowing the multidimensional nature of acculturation, the attempt to measure acculturation with the use of language preference and/or generation level is not powerful enough to establish generalizations about a population group. Acculturation is not simply the acquisition of a new language. Instead, language is contributory to acculturation, as well as other factors, such as adaptation to values, food preferences, beliefs, quality of interpersonal relationships, and other elements of a culture which encompass the complex concept of acculturation (Cortéz \& Rogler, 1994). Unfortunately, many studies including all of the segments of HHANES have used one or both of the above-mentioned variables as the only measure(s) of acculturation (Solis et al.; Pawson et al.).

The literature review suggests that a significant number of researchers have attempted to measure acculturation and develop different acculturation scales for Hispanics (Barona \& Miller, 1994; Bermúdez et al., 2000; Cortéz \& Rogler, 1994; Dana, 1996; Gardner et al., 1995; Gómez, 1990; Khan et al., 1997; Marín \& Gamba, 1996; Romero-Gwynn et al., 1993; Romero-Gwynn et al., 2000; Sánchez \& Fernández, 1993; Solis et al., 1990). Unfortunately, acculturation is typically assessed by unidimensional measures (Barona \& Miller; Gardner et al.; Khan et al.; Lee et al., 1999b; Solis et al.). Unidimensional scales erroneously and commonly consider the acculturation process as a 
zero sum behavior in which an individual progresses from an Hispanic pole to an American pole (Marín and Gamba).

Dana (1996) presented various acculturation scales such as the Acculturation Rating Scale for Mexican Americans (ARSMA/ARSMA-II); the Cultural Life Style Inventory (CLSI); the Bicultural/Multicultural Experience Inventory (B/MEI); and the Measure of Acculturation (MOC). In the ARSMA, four factors were used (i.e., language use and preference; ethnic identity and classification; cultural heritage and ethnic behaviors; and ethnic interaction) to measure acculturation via a 20 -item instrument.

The CLSI is a 29-item tool to address the following dimensions: interfamilial and extrafamilial language usage, social affiliations, cultural familiarity, and cultural identification/pride. The $\mathrm{B} / \mathrm{MEI}$ is a 57 -item questionnaire that includes information on demographics, personal history, and multicultural participation. The MOC is composed of a 20-item questionnaire measuring sociocultural information and affective ratings.

Negy and Woods (1992) discussed different studies that have addressed acculturation as well as two models that attempted to explain the acculturation patterns of Hispanic Americans. These models are "acculturation to the majority" and the "acculturation to the barrio" (Negy \& Woods). The former can be defined as the process by which successive Hispanic generations subscribe to the values and beliefs of the American culture, whereas the latter suggests that consecutive generations would acculturate to the norms of a barrio where many of the Hispanics' characteristics, values, and beliefs are perpetuated (Negy \& Woods). However, this model has some limitations considering that it does not allow for other possible acculturation patterns. Among the other studies discussed by Negy \& Woods were those from Berry (1980), Keefe and 
Padilla (1987), and Sabogal, Marín, Otero-Sabogal, Marín, Peréz-Stable (1987). Berry directed a three-phase acculturative stress model: contact, conflict, and adaptation. Keefe and Padilla presented a multidimensional model that endorses the concept of selective acculturation, whereby an individual can adopt specific values of a new culture while retaining other traditional values and customs. Sabogal et al. investigated various dimensions of familism and acculturation among three Hispanic subgroups where the dimensions of the scale were based on familial obligations, perceived support from the family, and family as referents.

The study of Cortéz and Rogler (1994) attempted to examine the involvement of Puerto Ricans in both Puerto Rican and American cultures avoiding assumptions of mutual cultural exclusivity. The scale (20-item questionnaire) that was used in this study was developed through the use of focus groups. The variables used in the questionnaire were language preference and usage, values, ethnic pride, food preferences, child-rearing practices, and interpersonal relations. The questionnaire consisted of ten questions that reflected the degree of involvement in the Puerto Rican culture and ten questions reflecting the degree of involvement in the American culture. Therefore, the two sets of items were equivalent. The only difference was the culture to which they referred. In this questionnaire, food preference was addressed with just one question: How many days a week would you like to eat Puerto Rican/American food?

Sánchez \& Fernández (1993) attempted to examine the acculturative stress among Hispanics by using a bidimensional model of ethnic identification. The following variables were used for this study: Hispanic identification, American identification, acculturative stress, stress induced by perceived discrimination, and other demographics. 
Marín \& Gamba (1996) developed a new scale of acculturation, the Bidimensional Acculturation Scale for Hispanics (BAS). The BAS included topics such as language use and preference within different contexts, for example with relatives, friends, individuals at work and other opportunities for interaction. The BAS also included the ability to use both the English and Spanish languages; language-based media preferences; preference for culture specific meals, celebrations, holidays, literature and music; and ethnicity of friends, significant others and/or spouse. Demographic questions were also included.

Gómez (1990) attempted to explore the relationship between biculturalism and mental health among Cuban Americans. The study used the following variables: psychological well-being, self-esteem, marital adjustment, job satisfaction, and biculturalism. An adaptation of the Latino Bicultural Assessment Questionnaire (LABIA) was used to measure biculturalism. This was a 45-item questionnaire with a Five-Point Likert-scale format. The factors used in this questionnaire were language use and preference, ethnic identity and cultural contact, and ethnic social interaction.

Khan et al. (1997) examined the relationship between acculturation and obesity in Hispanic Americans. The sample consisted of Mexican Americans, Cuban Americans, and Puerto Ricans from HHANES. In this study, the two indicators of acculturation were generation status (length of stay) and language preference.

Solis et al. (1990) studied the association among acculturation, access to care, and use of preventive services by Hispanic Americans. Again, the sample used was based on the 1982-84 HHANES. Two variables (language and ethnic identification) with three 
components were used to measure acculturation: spoken language, written language, and ethnic identification.

Barona \& Miller (1994) presented an acculturation scale to discuss the Hispanic cultural behaviors from both the appendage of the family and the appendage of extrafamilial social and media influences. In this study, they used one variable to measure acculturation and language. The Short Acculturation Scale for Hispanics (SASH), developed by Marín, Sabogal, Marín, Otero-Sabogal, and Pérez-Stable (1987), was used in this study in a modified form. Although this scale (SASH) has only one variable to measure acculturation, it was used as the basis for the Barona's study in view of adequate validity and concurrent reliability.

Gardner et al. (1995) attempted to investigate the relationship between dietary intake and acculturation among Hispanic males. Unfortunately, the questionnaire contained only one question pertaining to food: What type of food do you prefer? Other variables were Hispanic versus Anglo self-classification, preferences for language, movies, television, radio, friends, and music.

\section{Shortcomings of the Methods that Have Been Used}

The most significant shortcomings with acculturation scales for Hispanic Americans are the apparent lack of agreement among researchers on a definition and assessment device for acculturation, which has led to conflicting findings (Negy \& Woods, 1992; Gutmann, 1999). Another weakness in present most acculturative scales is the fact that researchers have seldom measured various areas of acculturative change, with language and generation levels being the preferred acculturation measures. In view 
of the multidimensional nature of the acculturation process, trying to measure acculturation with one or two variables may not be powerful enough to establish generalizations of a population group. Furthermore, acculturation is often considered as unidimensional process (Cortéz \& Rogler, 1994; Gardner et al., 1995; Gutmann; Marín \& Gamba, 1996; Negy \& Woods).

Marín and Gamba (1996) state that when researchers have attempted to measure acculturation, a common procedure has been the writing of items that a priori, are assumed to measure acculturation such as language preference and pattern of media use. Another significant difficulty has been that most scales have been designed to be used only with one Hispanic subgroup, which limits the instrument's generalizability and application in comparative cross-cultural studies (Marín \& Gamba). Future directions for the assessment of acculturation in domains other than language, for example, changes in dietary practices following migration to the United States, current consumption of traditional Hispanic foods, and association of dietary practices with level of acculturation, are needed (Gardner et al., 1995 and Cortéz and Rogler, 1994).

\section{Dietary Acculturation, How is it Measured?}

Information is inadequate on the dietary practices of Hispanic Americans (Chávez et al., 1994; Gardner et al., 1995). Although knowledge about Hispanic Americans' health conditions and status has expanded in the last decade, little is known about the relationship between their dietary practices and health (Gardner et al. and RomeroGwynn et al., 1993). Romero-Gwynn et al. stated that among the reasons for this lack of knowledge is the fact that most dietary studies among Hispanic Americans have seldom 
focused on the actual traditional foods and dishes. Instead, most studies have included foods that are generally consumed in the mainstream American diet (Romero-Gwynn et al.).

Few studies have attempted to measure the relationship between dietary intake patterns and acculturation. Among the studies that have assessed this relationship are the studies done by Aldrich and Variyam (2000); Bermúdez et al. (2000); Gardner et al. (1995); Lee et al. (1999a); Lee et al. (1999b); Romero-Gwynn et al. (1993); RomeroGwynn et al. (2000); Satia et al. (2000); Schultz et al. (1994). The major shortcoming of most of those studies is the fact that they measured acculturation independently of the dietary habits.

The studies by Romero-Gwynn et al. (1993); Romero-Gwynn et al. (2000); and Schultz et al. (1994) do not clearly explain the way in which acculturation was measured. However, in the study developed by Romero-Gwynn et al., 1993, different questionnaires were used for a better understanding of Mexican American food habits, demographic data, and how those variables correlate with one another. A questionnaire that evaluated food consumption retrospectively, prior to and after migration, was run among first generation Mexican Americans, a food frequency questionnaire (FFQ) was used for the second generation.

Schultz et al. (1994) used food records instead of food frequency questionnaires to assess the frequency of food consumption for a Chinese population. At the time of their study, a FFQ designed specifically for Chinese groups had not been developed.

Bermúdez et al. (2000) used a modified version of the acculturation scale of Cuellar, Harris, \& Jasso (1980) to explore the relationship between acculturation, 
ethnicity, length of residence in the United States, and macronutrient intake. This scale was based on the use of English, Spanish or English, and Spanish for speaking, reading or writing. Its acculturation score was based on the mean of these three language variables.

Lee et al. (1999b) measured dietary acculturation with a self-administered food frequency questionnaire (FFQ). The FFQ represented the consumption of American foods, Korean foods, and foods consumed in both America and Korea or what they called "common foods." Foods were divided into three groups: (1) "common foods" or foods that are consumed frequently in both Korea and America, (2) "American foods," foods usually consumed in America but rarely consumed in Korea, and (3) "Korean foods" which were foods consumed frequently in Korea but rarely in America.

Although Gardner et al. (1995) included a FFQ in the study, the instrument used to measure acculturation was a 17 -item questionnaire in which only one question pertained to food. Lee et al. (1999b) also included a FFQ; however, acculturation was measured on the basis of a two-culture matrix model and three acculturation dimensions (acculturated, bicultural, and traditional), which included the youngest, the most comfortable in the American society, and the most fluent in the English language (the latter being the most acculturated). Bicultural persons were those who had strong relationships with and high social participation in both American and Korean society. Traditional persons were those who felt most comfortable in the Korean society and with the Korean language, as well as oldest in age.

Pan, Dixon, Himburg, \& Huffman (1999) studied the changes in dietary patterns among Asian students before and after migration to the host American society. In this study, a food frequency list and questionnaire were developed to determine the average 
consumption of foods and to obtain data about sociodemographic characteristics. They found that Asian students were consuming only two meals per day; more salty and sweet snacks, as well as more fruits and dairy products; however, less meat, meat alternatives, and vegetables after immigration to the United States. Although researchers have attempted to study the relationship between changes in dietary habits and acculturation to the dominant American culture, more research is needed in this area (Chávez et al., 1994; Gardner et al., 1995).

\section{Why Measure Acculturation?}

The total percentage and the risk of chronic diseases can be substantially reduced by healthy eating habits (F \& NB, CLS/NRC, 1989; and Glanz \& Kolonel, 1998). Eating habits are influenced by cultural and social factors among others (Chávez et al., 1994; and Glanz \& Kolonel). Health advantages of the traditional Hispanic diet versus the traditional American diet has been recognized (Aldrich \& Variyam, 2000; and Gardner et al., 1995). The prevalence of chronic diseases varies between Hispanics and nonHispanic Whites (Chávez et al.). As Hispanics become more acculturated, their prevalence rate for the onset of chronic diseases increases (Aldrich \& Variyam; and Chávez et al.). Eating habits are altered in a new cultural environment or are shaped by culture (Chávez et al.; Moreno, 1997; Lee, 1999a). As acculturation increases, Hispanic Americans tend to have dietary habits that simulate those of the American population (Aldrich \& Variyam; Gardner et al.).

The process of acculturation encompasses different domains other than language, length of stay or generation level. Although language use and preference plays an 
important role when attempting to measure acculturation, food preferences and other elements of a culture such as interpersonal relationships, adaptation to values, and behavioral amenities are also contributory to its measurement (Cortéz \& Rogler, 1994).

There is limited data on the qualitative aspects of Hispanic foods, such as food preparation methods, changes in dietary practices following migration to the United States, and association of dietary practices with level of acculturation and health (Gardner et al., 1995; and Romero-Gwynn et al., 1993). Little or no information is available on Cuban American dietary changes after immigration. Gardner et al. suggested a need for future studies with the Hispanic population that will investigate nutrient intakes as well as other aspects of dietary behavior.

How Does Post-Migration Dietary Changes Affect the Rest of the Acculturation Process?

There is paucity of information about the effect that diet and disease have on the acculturation process in the literature. Moreover, researchers have seldom measured various areas of acculturative stress (Marín \& Gamba, 1996). However, it has been stated in the literature that there is need for the development of acculturation-assessment tools that encompass domains other than language use and preference and/or generation level (Cortéz \& Rogler, 1994; Gardner et al., 1995; Lee et al., 1999b; Marín \& Gamba; Negy \& Woods, 1992). Gardner et al. attempted to address this issue while studying the dietary intake patterns and acculturation levels of Hispanic immigrants. In their study, the needs for a better understanding of specific healthy or unhealthy Hispanic postmigration dietary changes were recognized. Furthermore, the researchers recognized that there was a need for future research on such aspects as dietary behaviors and current 
Hispanic American's nutrient intakes. Unfortunately, in their study, acculturation was measured with a seventeen-item questionnaire in which questions mostly pertained to language preference and language use, with only one question related to diet.

Acculturation outcomes result from a broad range of experiences. The length of exposure to the new culture, education, ability of the immigrants to speak or read the new language, socioeconomic status, social contact with people of the new culture, and food habits are among some of the different domains that encompass the complex concept of acculturation (Chávez et al., 1994; Gardner et al., 1995; \& Pan et al., 1999). Therefore, Marin and Gamba (1996) suggest that there is a need for the development of multidimensional scales to measure acculturation.

\section{Acculturation Effects on Diet, Disease, Health, And Alcohol}

Hispanics are the second-fastest growing minority group in the United States; it is believed that within the next 50 years, Hispanics will become the largest minority group (Aldrich \& Variyam, 2000; Council on Scientific Affairs, 1991; Hajat et al., 2000; and National Institute of Health, National Institute of Health and Kidney Disease, 1997). The Spanish language is the common denominator among Hispanics. However, in terms of culture, values, food habits, socioeconomic factors, and health status they are very heterogeneous (Moreno, 1997; Hajat et al., 2000; Rogler, 1991).

It is stated in the literature that dietary patterns (eating habits) are associated with chronic diseases (Aldrich \& Variyam, 2000; Council on Scientific Affairs, 1991; F \& NB, CLS/NRC, 1989; Glanz \& Kolonel, 1998; Pawson, 1991). In addition, the risk of developing many of the major chronic diseases such as cancer, diabetes, and coronary 
heart disease could be substantially reduced through specific dietary change (F \& NB, CLS/NRC). Aldrich and Variyam stated that less acculturated Hispanics (those who do not use English) eat somewhat more healthful diets than Hispanics who are English speakers. They also stated that Hispanic Americans' health and mortality records are in some respect more favorable than that of the general U.S. population, despite economic and educational disadvantages.

Westernization and assimilation among immigrants led to dietary changes and reduced physical activity, which are associated with increases in the onset of chronic diseases and obesity (Aldrich \& Variyam, 2000; Glanz \& Kolonel, 1998). Eating habits often change extensively after migration. According to the 1994-96 Continuing Survey of Food Intake by Individuals (CSFII) data, Aldrich and Variyam (2000) stated that Spanish speakers eat more healthful diets than do non-Hispanic Whites and Hispanics who are English speakers. It has been stated in the literature that many health behaviors worsen as people become more acculturated to the host American culture (Aldrich \& Variyam; Hajat et al., 2000). For example, Moreno (1997) found that immigrant Latinos are likely to eat only one or possibly two meals a day in this country as compared with three meals in their country of origin. This can be explained in terms of Hispanic Americans low socioeconomic status (National Institute of Health, National Institute of Health and Kidney Disease, 1995; Hajat et al.; Solis et al., 1990; Moreno). They often have two to three jobs, therefore, meals are eaten "on the run or whenever they have time" (Moreno, p. 439).

Heart disease is the leading cause of death among Hispanic Americans and in people with diabetes, especially Type 2 Diabetes (Moreno, 1997; and National Institute 
of Health, National Institute of Health and Kidney Disease, 1997). However, when Hispanics were compared with the general U.S. population, Hispanics had lower mortality from cancer and cardiovascular disease, but higher mortality from diabetes (Sorlie, Backlund, Johnson, \& Rogot, 1993). Diabetes in Hispanic Americans is a serious health problem because of the high prevalence of diabetes and the greater incidence of diabetes complications in this group (Aldrich \& Variyam, 2000; and National Institute of Health, National Institute of Health and Kidney Disease). According to HHANES data, $15 \%$ of the Cuban Americans have Type 2 Diabetes (National Institute of Health, National Institute of Health and Kidney Disease). The prevalence of diabetes among Cuban Americans is $30-50 \%$ higher than that of non-Hispanic Whites (National Institute of Health, National Institute of Health and Kidney Disease). Adults with diabetes are more likely than non-diabetics to suffer from hypertension, hyperlipidemia, and heart disease (National Institute of Health, National Institute of Health and Kidney Disease; Flegal et al., 1991; Frazao, 1996). However, the increased risk of heart disease related with diabetes appears to be independent of these factors (National Institute of Health, National Institute of Health and Kidney Disease). In that sense, genetics seems to play an important role in the onset or development of diabetes (Garza, 1995). American Indians and African American populations have a higher prevalence of diabetes (National Institute of Health, National Institute of Health and Kidney Disease). Perhaps those ethnic groups that are a mixture of these population groups (American Indians and African Americans), as is the case of Hispanics are even more predisposed to develop diabetes than others are (National Institute of Health, National Institute of Health and Kidney Disease). On the other hand, certain health characteristics such as cardiovascular 
disease, mortality, hypertension, and pregnancy outcomes seems to follow a more complex pattern, one that is closely associated with both socioeconomic status and acculturation levels (Aldrich \& Variyam; and Hajat et al., 2000).

The relationship between low socioeconomic status and health risk has been discussed in the literature (National Institute of Health, National Institute of Health and Kidney Disease, 1995; Angel \& Guarnaccia, 1989; Flegal, 1991; Hajat, 2000). Persons with high socioeconomic status generally have better health outcomes than those with low socioeconomic status (Hajat). It is implied in the literature that Hispanic Americans, as a group, have a lower socioeconomic status than non-Hispanic Whites (National Institute of Health, National Institute of Health and Kidney Disease; Angel \& Guarnaccia; Flegal; Solis et el., 1990; and Hajat). However, despite Hispanic Americans' lower incomes and education, they enjoy a health and mortality record that in many regards is more favorable than that of the general population (Aldrich \& Variyam, 2000). Among Hispanic Americans, Cuban Americans who came to the United States in the 1960s tended to have a fairly high socioeconomic status (Whitney, 1998; Lang, 1992; Sanjur, 1995). For many low income Hispanics, survival (e.g., paying the rent) is the primary concern while preventive health issues are often a secondary consideration (Moreno, 1997).

Somatization is a psychiatric disorder characterized by recurring clinically significant physical complaints such as depression, anxiety, vegetative signs, and gastrointestinal (GI) problems that cannot be explained by a physical disorder (Angel \& Guarnaccia, 1989). Hispanics are more likely than non-Hispanics to suffer somatoform problems (Angel and Guarnaccia). This disorder is prevalent in developing societies and 
among immigrants with lower levels of acculturation and low socioeconomic status.

Somatization may result in greater use of medical services secondary to depression, changes in appetite, sleep patterns, and energy levels (Angel \& Guarnaccia). Physiologic changes linked to depression as well as medical, social and environmental factors can be the cause of eating disorders and malnutrition (Marcus \& Berry, 1998).

It is believed that immigration is likely to cause disruption of attachments to supportive networks in the society of origin and force the immigrants the difficult task of annexation into the primary group of the main society (Rogler, Cortéz, \& Malgaldy 1991). However, the absence of instrumental skills such as English makes the process of assimilation or the feeling of belonging worse, lowers self-esteem and eventually gives rise to symptomatic behavior (Rogler et al.). Immigrants' poverty and low acculturation levels may be associated with low self-esteem, self-depreciation, alcoholism, poor physical health and may end in ethnic self-hatred (Rogler et al., 1991).

Researchers have found that drinking patterns increase with increases in acculturation (Negy \& Woods, 1992). Acculturation and its inherent stress may directly influence not only the prevalence of drinking and the number of alcohol-related problems found among Hispanic Americans, but also their expectations concerning the consumption of alcoholic beverages (Marín et al., 1993). The effect of acculturation on alcohol consumption seems to have less of an effect on men than on women (Rogler et al., 1991; Marín et al.; Whitney, 1998). Although it is well documented that Hispanic women consume less alcohol than do their male counterparts, acculturation levels are related to greater alcohol consumption especially among young Hispanic women (Marín et al.; Whitney). Higher acculturation levels (to the American culture) by Hispanic 
women may mean a lesser adherence to traditional cultural norms or roles (Whitney).

Therefore, Hispanic women tend to ignore taboos associated with women's alcohol consumption. Thus, their drinking patterns may then become more like those of American women (Whitney). Hispanic American men appear to drink less frequently, but in higher quantities than do American men. Unfortunately, heavy drinking can end in alcohol-related morbidity and mortality, which may place Hispanic Americans at a high health-risk (Whitney). Excessive drinking of alcohol has been linked with heart disease, high blood pressure, chronic liver disease, and nutritional deficiency (F \& NB, CLS/NRC, 1989).

Researchers that studied acculturation with Hispanic immigrants most of the time ignored the way these people ate or behaved if they were in their country of origin, therefore, erroneously attributing differences in behaviors to the impact of the U.S. culture (Gutmann, 1999). The lack of knowledge among researchers about Hispanic cultures limits their ability to account for changes in behavioral norms, values, and alcohol consumption behavior that may be related to cultural factors (Gutmann). 


\section{PURPOSE OF THE RESEARCH}

The primary purpose of this study was to establish baseline information on how acculturation affects Cuban Americans' dietary habits. Secondly, the purpose of the study was to determine whether acculturation had a different impact on Cuban Americans with Type 2 Diabetes versus those without diabetes. In addition, the study attempted to explore whether any differences existed in post-migration dietary patterns between Cuban Americans with Type 2 Diabetes and/or those without. Finally, the study also correlated alcohol consumption and acculturation among Cuban Americans with Type 2 Diabetes and non-diabetics.

Hispanic Americans have the highest rate of Type 2 Diabetes compared to nonHispanic Americans (National Institute of Health, National Institute of Health and Kidney Disease, 1995; \& National Institute of Health, National Institute of Health and Kidney Disease, 1997). The most common cause of death among persons with diabetes is Coronary Heart Disease (CHD) (National Institute of Health, National Institute of Health and Kidney Disease, 1995; Moreno, 1997; and National Institute of Health, National Institute of Health and Kidney Disease, 1997). However, it has been found that Hispanics have lower rates of CHD despite having higher rates of diabetes (Garza, 1995; Mitchell et al., 1992; Rewers, Shetterly, Baxter, Marshall, \& Hamman, 1992; Sorlie et al., 1993; National Institute of Health, National Institute of Health and Kidney Disease, 1997). Researchers have tried to explore the association between diabetes and diet (Garza; \& Hamman, et al.,1989). Nevertheless, most of these studies were conducted in the United States, therefore, when dealing with Cuban Americans who are living in the 
United States, the following questions appear: Are Cuban Americans acculturated to the American culture? Do Cuban Americans eat as Americans do? Are the Cuban Americans who have Type 2 Diabetes more acculturated into American culture compared to those who are non-diabetics?

\section{OBJECTIVES}

- Evaluate Cuban Americans' levels of acculturation to the host American culture.

- Evaluate the impact of acculturation on Cuban Americans' dietary patterns.

- Evaluate the difference in dietary acculturation among Cuban Americans who are NIDDM and non-diabetic.

\section{HYPOTHESES}

- The exclusion of Cuban foods and the inclusion of American foods in the diets of Cuban Americans are associated with higher levels of acculturation as measured by the Short Acculturation Scale for Hispanic Youth (SASH-Y).

- Type 2 Diabetic Cuban Americans eat more American foods than non-diabetic Cuban Americans.

- Type 2 Diabetic Cuban Americans drink less alcohol than non-diabetic Cuban Americans. 


\section{METHODOLOGY}

\section{$\underline{\text { Study Design }}$}

The study design used was a cross-sectional survey, a non-intervention study utilizing a convenient sample of Cuban Americans living in the Miami-Dade County (FL) area.

$\underline{\text { Subjects }}$

Cuban Americans with Type 2 Diabetes and without diabetes were included in the study. Ambulatory male and female subjects with an age range of 40 to 65 years were recruited through the use of flyers (Appendix A) describing the purpose of the study. The flyers were distributed in supermarkets, a physician's office, an outpatient diabetic clinic, and among the employees and their relatives at Pan American Hospital. These places were located strategically where Cuban Americans conduct business and seek health care. Inclusion/Exclusion Criteria for the Selection of Subjects

The inclusion criteria included were:

- Cuban American

- Between 40-65 years of age

- Diagnosed with Type 2 Diabetes

- Volunteer to participate in the study

- Be willing to sign an informed consent document (Appendix B)

The exclusion criteria included:

- Non-Cuban

- Be less than 40 or more than 65 years old 
- Diagnosed Type 1 Diabetes

- Have renal disease

- Currently dieting (Atkins; liquid and formulas, e.g., Slim fast; and low protein diets)

- Not willing to participate in the study

- Refuse to sign the informed consent form

All steps of the research study and objectives were explained to the subjects. Furthermore, the informed consent form described the objectives and methods of the research study. Any information provided by the subjects was treated anonymously. A sample of 178 subjects was included in the study. The Institutional Review Board (IRB) approval for the Human Subjects study protocol was obtained from the IRB Committee at Florida International University (FIU) (Appendix C).

Instrument / Multidimensional Acculturation Survey

A review of the literature, described earlier, revealed that the most common acculturation tools are language use, language preference, and length of stay in the host country. Demographic data and self-identity were also included in the acculturation tools. Food preference and dietary habits after migration were inadequately addressed and assessed by those acculturation tools. A Multidimensional Acculturation Survey for Cuban-Americans (MAS-CA) was developed for use in this study (Appendix D). The MAS-CA included a Dietary Bidimensional Acculturation Scale (D-BAS). This survey attempts to address many of the shortcomings of the previous surveys. The D-BAS can be utilized with different ethnic groups after a few modifications such as changing the traditional Cuban foods for the traditional foods of the ethnic group involved, as well as 
changing the questions to reflect the corresponding nationality. Only Cuban Americans were used for this study. The survey was composed of a dietary section (D-BAS) which included the subject's age and gender, the presence or absence of either Type 1 or Type 2 Diabetes. Also, subjects were asked if they were dieting. After this, the use of two food frequency tables followed. The first table included thirteen traditional Cuban foods commonly consumed in Cuba by Cubans, whereas the second table included thirteen food items commonly consumed in the USA but that were rarely or not consumed at all in Cuba. To avoid bias, the table that related to Cuban foods was identified with the letter "A" and the table that related to American foods was identified with the letter "B." For each food item included in the D-BAS, subjects were asked to indicate the frequency of food items consumed: $0=$ "never", 1 ="one per month", $2=$ ="two per month", $3=$ ="one to two per week", 4="three to six per week", or 5="one or more per day". The scores on both food frequency tables ranged from 0 to 65 , with the higher scores indicating more frequency in eating either Cuban or American food items. The survey also included eleven questions to measure demographics and social behavior, three questions to measure alcohol consumption, two questions to address psychosocial issues, and four questions related to language as adopted from the SASH-Y (Barona \& Miller, 1994).

The development of the survey involved three major steps. First, the subject's measurable characteristics (e.g., demographic data, alcohol consumption, diet, language, and psychosocial beliefs), as mentioned in the literature and as they relate to an individual's acculturation level were identified and included in the survey to reflect two cultural orientations: a Hispanic cultural domain and a non-Hispanic domain. Also, a review of the literature led to the identification of ten traditional Cuban foods and ten 
traditional American foods (Bonnie, 1999; Bowman, Lino, Gerrior, \& Basiotis; Sanjur, 1995). Those initial food items were discussed with two professors at FIU, one of them being an expert in nutrition. In the second step, a focus group composed of four first generation Cubans was used to discuss the food items included in the D-BAS. The discussion consisted of the identification of the ten most commonly consumed traditional Cuban food items by Cubans in Cuba and the ten most commonly consumed American foods rarely or never consumed in Cuba. All of the American foods included in the DBAS were modified after the focus group discussions.

The third step consisted of a pilot study to establish validity of this study. A pilot study was conducted to test concurrent validity of the survey. Feedback from the pilot testing was used to develop the final version of the scale. Questions \#12 and \#13 of the survey, which relate to alcohol consumption, were modified after the pilot study. The acculturation score was measured using four questions from the SASH-Y (Barona \& Miller, 1994), the ones relating to language used and preference. These questions have been successfully used in previous acculturation scales (Barona \& Miller). Therefore, the inclusion of those questions in the MAS-CA allowed the measurement of concurrent validity of the new scale. The acculturation score ranged from one (using only Spanish) to five (using only English) and was constructed by averaging questions 15-18 in the questionnaire (Appendix E). Results of the pilot study showed that the D-BAS had a significant negative correlation $(\mathrm{r}=-0.502 ; \mathrm{P}<0.05)$ between the Cuban Food Score and the Acculturation Score.

One of the survey's questions was an open-ended question that read, "What five food items do you consume now that you consider to be traditional?" This question was 
designed to validate the new scale included in the survey (D-BAS). The MAS-CA was written in English and Spanish. In the MAS-CA Spanish version, some items were in English because most Cuban Americans recognize them as such (e.g., cheesecake, bagel, frozen yogurt, etc.).

\section{Data Collection:}

The investigator visited the designated locations on Wednesdays, Saturdays, and Sundays during a period of five months. Subjects were asked to complete a selfadministered survey (after signing a brief informed consent as proof of their authorization). Subjects were aware that their responses would be used solely for research purposes and would be kept anonymously. They were asked to complete the survey in the language of their choice, English or Spanish.

The data collection took place at Publix Super Market, Food Start Super Market \#3, a physician's office, an outpatient diabetic clinic, and Pan American Hospital, all in the Miami, Florida area. For the data collection that took place at Publix and at Food Start Supermarkets \#3, a table with chairs was provided for the subjects to complete the survey. Subjects were not allowed to talk or make comments with other participants while filling out the survey. However, participants were allowed to question the investigators, who were Registered Dietitians. After the completion of the survey, as a reward, the investigators gave the participants a tour around the supermarket explaining the different healthy products available and how to select healthy alternatives. Statistical Analysis:

The data were analyzed using SPSS for Windows (v. 10). Statistical procedures such as frequencies, means, standard deviations, Pearson's correlations, and t-tests were 
performed. Gender, presence or absence of diabetes, dietary pattern, language use and preference, and alcohol consumption were used in the analysis. Questions 15-18 in the MAS-CA (relating to language) were used to measure acculturation. T-test and percentages were used to analyze questions 12-14 of the MAS-CA (relating to alcohol consumption). A P value of $<0.05$ was considered statistically significant. 


\section{RESULTS}

Descriptive summary statistics and demographic and socioeconomic characteristic of the subjects are presented in Tables 1 and 2. All of the subjects $(n=178)$ were first generation Cuban Americans. Mean ( \pm SD) age was $58.2 \pm 10.0$ years. Sixty-eight percent of the subjects $(n=121)$ were women and $32 \%(n=57)$ were males. Thirty- two percent $(n=57)$ of the subjects were diabetic. Among the diabetics, fifty-five $(97 \%)$ had non-insulin dependent diabetes mellitus (NIDDM) and two (4\%) had insulin dependent diabetes mellitus (IDDM). The majority $(92 \% ; n=163)$ of the respondents reported living in a "Hispanic Barrio." The highest educational level completed by most subjects was high school $(\mathrm{n}=59 ; 33.1 \%)$ followed by equal numbers of subjects who completed a bachelor's degree $(n=35: 19.7 \%)$ and those who completed more than a bachelor's degree $(\mathrm{n}=35 ; 19.7 \%)$. Twenty-seven $(15.2 \%)$ subjects had completed an associate's degree. Only $12.4 \%$ of the subjects had completed elementary school $(n=22)$. Of the total population, three quarters $(75.6 \%)$ reported having an income $\leq \$ 24,000$.

The acculturation score of this sample of Cuban Americans was $1.73 \pm 0.85$ on a scale from 1 to 5 . The acculturation score was calculated by obtaining a mean score from questions $15-18$ of the acculturation questionnaire (Appendix E). The answers to questions 15-18 were scored as follows: 1="only Spanish," 2="more Spanish than English," 3="both equally," 4="more English than Spanish," and 5="only English." Therefore, in scoring the means, the higher the number obtained, the more English the subjects used and the more acculturated they were into the American culture. Table 3 consists of preference of language usage by the subjects. Seventy percent of the subjects 
Table 1. Diabetes Status of the Subjects

\begin{tabular}{|c|c|c|c|}
\hline Characteristic & $\mathbf{N}$ & Percent $(\%)$ & Mean Age \pm SD \\
\hline Total subjects & 178 & 100 & $58.2 \pm 10.0$ \\
\hline Male & 57 & 32 & $57.1 \pm 10.3$ \\
\hline Female & 121 & 68 & $58.8 \pm 9.9$ \\
\hline Non-diabetic & 119 & 67.6 & $55.4 \pm 9.1$ \\
\hline Male & 39 & 32.8 & $53.7 \pm 9.9$ \\
\hline Female & 80 & 67.2 & $56.0 \pm 8.6$ \\
\hline Diabetic & 57 & 32.4 & $64.8 \pm 8.8$ \\
\hline Male & 18 & 31.6 & $64.4 \pm 7.1$ \\
\hline Female & 39 & 68.4 & $65.0 \pm 9.5$ \\
\hline Total NIDDM* & 55 & 96.5 & $64.9 \pm 8.9$ \\
\hline Male & 16 & 29.1 & $64.8 \pm 7.5$ \\
\hline Female & 39 & 70.9 & $65.0 \pm 9.5$ \\
\hline Total IDDM ${ }^{* *}$ & 2 & 3.5 & $61.0 \pm 1.4$ \\
\hline Male & 2 & 100 & $61.0 \pm 1.4$ \\
\hline Female & 0 & 0 & 0 \\
\hline
\end{tabular}

* Non Insulin Dependent Diabetes Mellitus

** Insulin Dependent Diabetes Mellitus 
Table 2. Demographic and Socioeconomic Characteristics of the Subjects

\begin{tabular}{|l|r|r|}
\hline \multicolumn{1}{|c|}{ Variable } & N & \multicolumn{2}{|c|}{ Percent (\%) } \\
\hline Cuban Origin & 178 & 100 \\
Years Lived in USA & & \\
$<5$ & 21 & \\
$6-10$ & 18 & 11.9 \\
11 & 138 & 10.2 \\
& & 78.0 \\
Living in a Hispanic Barrio & 163 & \\
Yes & 14 & \\
No & & 91.6 \\
& & 7.9 \\
Education: & 22 & \\
Elementary school & 59 & 12.4 \\
High school & 27 & 33.1 \\
Associate degree & 35 & 15.2 \\
Bachelor's degree & 35 & 19.7 \\
Above Bachelor's degree & & 19.7 \\
& & \\
Income & 129 & \\
$\leq$ \$24,000 & 18 & 75.9 \\
\$25,000 - 36,000 & 16 & 10.6 \\
\$36,000-50,000 & 7 & 9.4 \\
$\geq \$ 50,000$ & & \\
& & \\
\hline
\end{tabular}


Table 3. Preference of Language Usage by the Subjects

\begin{tabular}{|c|c|c|}
\hline $\begin{array}{l}\text { Language of preference in } \\
\text { performing the followings tasks: }\end{array}$ & $\mathbf{N}$ & Percent (\%) \\
\hline \multicolumn{3}{|l|}{ Speak at Home } \\
\hline Only Spanish & 125 & 70.8 \\
\hline More Spanish Than English & 27 & 15.2 \\
\hline Both Equally & 20 & 11.5 \\
\hline More English Than Spanish & 4 & 2.2 \\
\hline Only English & 1 & 0.6 \\
\hline \multicolumn{3}{|l|}{ Think } \\
\hline Only Spanish & 125 & 70.2 \\
\hline More Spanish Than English & 26 & 14.6 \\
\hline Both Equally & 20 & 11.2 \\
\hline More English Than Spanish & 5 & 2.8 \\
\hline Only English & 2 & 1.1 \\
\hline \multicolumn{3}{|l|}{ Speak Among Friends } \\
\hline Only Spanish & 106 & 59.6 \\
\hline More Spanish Than English & 48 & 27 \\
\hline Both Equally & 19 & 10.7 \\
\hline More English Than Spanish & 2 & 1.1 \\
\hline Only English & 2 & 1.1 \\
\hline \multicolumn{3}{|l|}{ Listen to the Radio or TV } \\
\hline Only Spanish & 68 & 38.2 \\
\hline More Spanish Than English & 41 & 23.0 \\
\hline Both Equally & 28 & 15.7 \\
\hline More English Than Spanish & 25 & 14.0 \\
\hline Only English & 16 & 9.0 \\
\hline
\end{tabular}


spoke and thought only in Spanish. However, only $38 \%$ of the subjects listened to the radio or TV only in Spanish.

Table 4 shows relative alcohol consumption by the subjects before and after immigration to theUSA. A larger percentage of non-diabetic subjects (44\%) stated they drank more after immigration than diabetic subjects (30\%). A preference list of foods, including the top 33 Cuban foods consumed by the subjects, is presented in Table 5. This list was developed from the subjects' answers to the open-ended question (What five food items do you consume now that you consider to be traditional?) that was included in the MAS-CA. This list includes English and Spanish versions, with description of the traditional Cuban foods according to the method of preparation. These tables made the validation of the D-BAS possible by confirming that all the Cuban foods included in the D-BAS were truly traditional Cuban foods. The most preferred food item was stewed legumes (beans) and the least preferred food item was sausages.

\section{Dietary Pattern and Acculturation}

Dietary acculturation was measured as the consumption of Cuban and American foods, which indicated the degree of immersion into both cultures. Consumption information was obtained from a self-administered food frequency questionnaire, the DBAS, score ranging from 0-65. The Cuban Food Score (CFS) was compared with the American Food Score (AFS) using a t-test. The CFS (31.8 \pm 9.4$)$ was significantly higher $(\mathrm{P}<0.001)$ than the AFS $(15.7 \pm 8.6)$. A significant negative relationship ( $\mathrm{r}=-$ $0.334 ; \mathrm{P}<0.001$ ) was observed between the CFS and the acculturation score, which related to language (Figure 1). 
Table 4. Alcohol Consumption Among Subjects Who Drink

\begin{tabular}{|l||c|c|c|c||c|c|}
\hline \multicolumn{1}{|c||}{} & \multicolumn{2}{c|}{ All Subjects } & \multicolumn{2}{c|}{ Diabetic } & \multicolumn{2}{c|}{ Non-diabetic } \\
\hline Subjects who drink: & N & $\%$ & N & $\%$ & N & $\%$ \\
\hline More now than before immigration & 35 & 40.7 & 7 & 30.4 & 28 & 44.4 \\
Equal than before immigration & 25 & 29.1 & 7 & 30.4 & 18 & 28.6 \\
Less than before immigration & 26 & 30.2 & 9 & 39.1 & 17 & 27.0 \\
\hline \multicolumn{1}{|c|}{ Total } & 86 & 100.0 & 23 & 100.0 & 63 & 100.0 \\
\hline
\end{tabular}


Table 5. Top food items consumed most frequently by Select Cuban Americans in Miami

\begin{tabular}{|c|c|c|c|}
\hline $\begin{array}{c}\text { Spanish Version with } \\
\text { Description }\end{array}$ & $\begin{array}{l}\text { American Version with } \\
\text { Description }\end{array}$ & $\mathbf{N}$ & $\begin{array}{l}\text { Percent } \\
(\%)\end{array}$ \\
\hline $\begin{array}{l}\text { Potaje, cualquier legumbre } \\
\text { guisada. Pudiese añadírsele } \\
\text { puerco, salchichas, tocino, como } \\
\text { también viandas. }\end{array}$ & $\begin{array}{l}\text { Stew legumes (beans), any } \\
\text { legumes that may be cooked with } \\
\text { pork, pork-sausages, salt pork, as } \\
\text { well as starchy vegetables }\end{array}$ & 117 & 65.7 \\
\hline $\begin{array}{l}\text { Arroz blanco, arroz blanco } \\
\text { cocido en agua, sal y aceite. }\end{array}$ & $\begin{array}{l}\text { White rice, white rice cooked } \\
\text { with water, salt, and oil }\end{array}$ & 115 & 64.6 \\
\hline Bistec & Beefsteak & 73 & 41.0 \\
\hline $\begin{array}{l}\text { Viandas, papa, calabaza, plátano } \\
\text { (maduro o verde), boniato, yuca, } \\
\text { malanga, y name hervido. Las } \\
\text { viandas son unos de los platos } \\
\text { principales del Cubano. }\end{array}$ & $\begin{array}{l}\text { Starchy vegetables, boiled potato, } \\
\text { pumpkin, green and ripe } \\
\text { plantains, sweet potato, cassava, } \\
\text { yam, and other roots. A very } \\
\text { popular entrée in Cuba }\end{array}$ & 72 & 40.4 \\
\hline $\begin{array}{l}\text { * Pollo frito, pollo frito en aceite } \\
\text { vegetal }\end{array}$ & $\begin{array}{l}\text { * Fried chicken, chicken fried in } \\
\text { vegetable oil }\end{array}$ & 48 & 27.0 \\
\hline $\begin{array}{l}\text { * Masitas de puerco, trozos de } \\
\text { puerco fritos en aceite vegetal }\end{array}$ & $\begin{array}{l}\text { * Fried pork chunks, pork chunks } \\
\text { fried in vegetable oil }\end{array}$ & 39 & 21.9 \\
\hline $\begin{array}{l}\text { Frutas tropicales: fruta bomba, } \\
\text { naranja, banana, piña, mamey }\end{array}$ & $\begin{array}{l}\text { Tropical fruits: papaya, orange, } \\
\text { banana, pineapple, mamey }\end{array}$ & 31 & 17.4 \\
\hline $\begin{array}{l}\text { Ensalada, lechuga y tomate con } \\
\text { aceite vegetal y vinagre }\end{array}$ & $\begin{array}{l}\text { Salad, lettuce and tomatoes with } \\
\text { vegetable oil and vinegar }\end{array}$ & 28 & 15.7 \\
\hline $\begin{array}{l}\text { * Pescado frito, pescado frito } \\
\text { (empanizado) en aceite vegetal }\end{array}$ & $\begin{array}{l}* \text { Fried fish, fish breaded and } \\
\text { fried in vegetable oil }\end{array}$ & 20 & 11.2 \\
\hline Sopa de pollo & Chicken soup & 20 & 11.2 \\
\hline $\begin{array}{l}\text { Ropa vieja, carne de vaca, } \\
\text { desmenuzada y guisada }\end{array}$ & $\begin{array}{l}\text { Shredded beef, stewed shredded } \\
\text { beef }\end{array}$ & 19 & 10.7 \\
\hline $\begin{array}{l}\text { Pan cubano, pan hecho con } \\
\text { manteca, levadura y sal. } \\
\text { Usualmente se come tostado con } \\
\text { mantequilla en el desayuno }\end{array}$ & $\begin{array}{l}\text { Cuban bread, non sweet roll made } \\
\text { with lard, yeast, and salt, usually } \\
\text { eaten toasted with butter for } \\
\text { breakfast }\end{array}$ & 18 & 10.1 \\
\hline Picadillo, carne de vaca molida & Stewed ground beef & 18 & 10.1 \\
\hline $\begin{array}{l}\text { Ajiaco, asopao de vegetales, } \\
\text { viandas y carne }\end{array}$ & $\begin{array}{l}\text { Boiled meat cooked with starchy } \\
\text { and non-starchy vegetables }\end{array}$ & 18 & 10.1 \\
\hline $\begin{array}{l}\text { * Maduros, plátanos maduros } \\
\text { fritos en aceite vegetal }\end{array}$ & $\begin{array}{l}\text { * Ripe plantains, fried in } \\
\text { vegetable oil }\end{array}$ & 17 & 9.6 \\
\hline
\end{tabular}

* Typically these foods are prepared with vegetable oil, but originally were prepared using lard in Cuba. 
Table 5. Continued

\begin{tabular}{|c|c|c|c|}
\hline $\begin{array}{c}\text { Spanish Version with } \\
\text { Description }\end{array}$ & $\begin{array}{l}\text { American Version with } \\
\text { Description }\end{array}$ & $\mathbf{N}$ & $\begin{array}{l}\text { Percent } \\
(\%)\end{array}$ \\
\hline $\begin{array}{l}\text { Congrí, arroz guisado con frijoles } \\
\text { negros, tocino y tocineta }\end{array}$ & $\begin{array}{l}\text { Rice with beans, rice cooked } \\
\text { with black beans, bacon, and salt } \\
\text { pork }\end{array}$ & 17 & 9.6 \\
\hline Leche entera & Whole milk & 13 & 7.3 \\
\hline Salpicón & Meat loaf & 10 & 5.6 \\
\hline $\begin{array}{l}\text { Tamal en cazuela, harina de maíz } \\
\text { tierno cocida con carne de puerco } \\
\text { y especias }\end{array}$ & $\begin{array}{l}\text { Tamal en cazuela, grounded } \\
\text { fresh corn cooked with spices } \\
\text { and pork meat }\end{array}$ & 8 & 4.5 \\
\hline $\begin{array}{l}* \text { Tostones, plátano verde } \\
\text { aplastado y frito. }\end{array}$ & $\begin{array}{l}\text { * Tostones, flattened and fried } \\
\text { green plantain }\end{array}$ & 7 & 3.9 \\
\hline Camarones enchilados & Shrimp criolle & 7 & 3.9 \\
\hline $\begin{array}{l}\text { * Huevo, huevo hervido, revuelto } \\
\text { o frito }\end{array}$ & $\begin{array}{l}\text { * Egg, boiled, scrambled or fried } \\
\text { egg }\end{array}$ & 6 & 3.4 \\
\hline $\begin{array}{l}\text { Arroz con pollo, arroz guisado con } \\
\text { pollo, chícharos y pimientos rojos }\end{array}$ & $\begin{array}{l}\text { Rice with chicken, white rice } \\
\text { cooked with chicken, chick peas, } \\
\text { and red peppers }\end{array}$ & 6 & 3.4 \\
\hline Aguacate & Avocado & 6 & 3.4 \\
\hline $\begin{array}{l}\text { Postres: arroz con leche, arroz } \\
\text { cocido con leche, azúcar y canela; } \\
\text { casco de guayaba; flan, postre } \\
\text { hecho con leche evaporada, leche } \\
\text { condensada, azúcar, huevo y } \\
\text { vainilla; dulce de coco; natilla }\end{array}$ & $\begin{array}{l}\text { Desserts: rice pudding, rice } \\
\text { cooked with milk and sweetened } \\
\text { with sugar and spiced with } \\
\text { cinnamon; guava shells in syrup; } \\
\text { flan, custard prepared with } \\
\text { evaporated and condensed milk, } \\
\text { sugar, eggs, and vanilla; grated } \\
\text { coconut in syrup; custard }\end{array}$ & 6 & 3.4 \\
\hline $\begin{array}{l}\text { Café Cubano, café negro con } \\
\text { azúcar servido en pequeños vasos } \\
\text { de } 1 / 2 \text { a } 1 \mathrm{oz} \text {. }\end{array}$ & $\begin{array}{l}\text { Espresso sweetened with sugar } \\
\text { served in } 1 / 2 \text { to } 1 \text { oz cups }\end{array}$ & 5 & 2.8 \\
\hline Cortadito, café con leche y azúcar & Espresso with milk and sugar & 3 & 1.7 \\
\hline Rabo encendido & Oxtail & 2 & 1.2 \\
\hline $\begin{array}{l}\text { Avena, avena cocida con leche, } \\
\text { vainilla, sal y azúcar }\end{array}$ & $\begin{array}{l}\text { Oatmeal, oatmeal cooked in milk } \\
\text { to which vanilla, salt, and sugar } \\
\text { is added }\end{array}$ & 2 & 1.2 \\
\hline Arroz con salchicha & Rice cooked with sausages & 2 & 1.2 \\
\hline Galletas Cubanas & $\begin{array}{l}\text { Cuban crackers, made with lard } \\
\text { and salt }\end{array}$ & 2 & 1.2 \\
\hline Mantequilla & Butter & 1 & 0.6 \\
\hline Salchichas & Sausages & 1 & 0.6 \\
\hline
\end{tabular}

* Typically these foods are prepared with vegetable oil, but originally were prepared using lard in Cuba. 


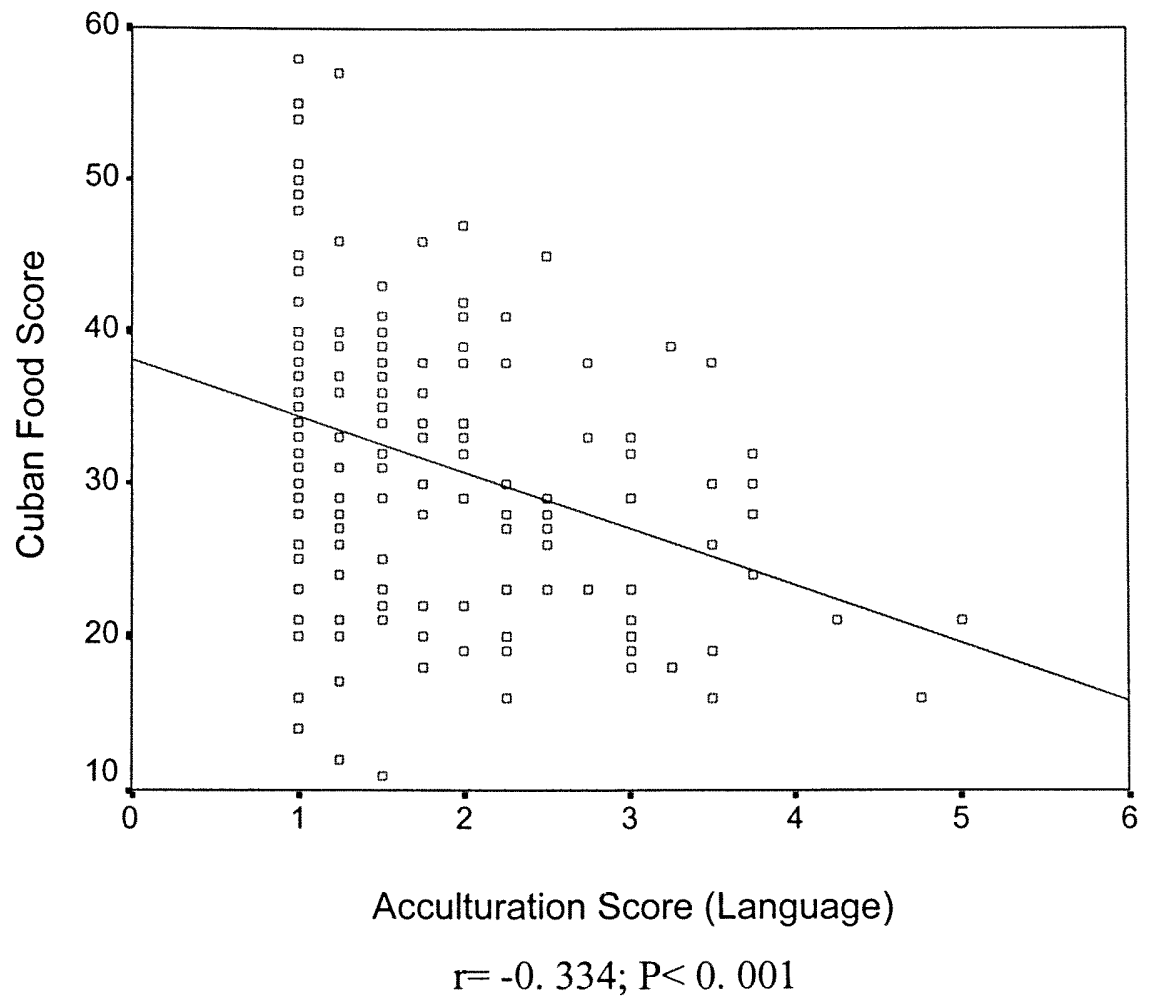

Figure 1. Correlation between the Cuban food score and the acculturation score in all subjects $(n=178)$. 
Those who were less acculturated ate more Cuban foods. No significant correlation was observed between the AFS and the acculturation score $(\mathrm{r}=0.056 ; \mathrm{P}=0.457)$ (Figure 2).

The subjects' acculturation scores were stratified into three subgroups, as shown in Table 6: those whose acculturation score were less than one $(n=62)$; those who had acculturation scores 1 to $1.99(n=56)$; and those with acculturation scores $2-5(n=60)$. T-tests were used to compare the CFS with the AFS within each subgroup. For all subgroups, the Cuban Food Score means $(35.3 \pm 10.1,31.4 \pm 8.8$, and $28.5 \pm 7.8)$ were significantly higher $(\mathrm{P}<0.001)$ than the American Food Score means $(15.2 \pm 10.5,15.5 \pm$ 6.7, and $16.4 \pm 7.9$ ). The analysis of variance (ANOVA) indicated that the CFS and the mean difference between the CFS and the AFS were significantly different across acculturation levels $(\mathrm{P}<0.001)$. No differences were found on AFS mean scores by acculturation level. Tukey's post hoc test at $\alpha=.05$ showed that the mean CFS for the most acculturated group $(28.5 \pm 7.8)$ was significantly less than for the lowest acculturated group $(35.3 \pm 10.1)$. Furthermore, post hoc tests showed that the mean differences between the CFS and the AFS for the most acculturated group (12.1 \pm 9.4$)$ and the middle acculturated group $(15.9 \pm 9.6)$ were significantly smaller than that of the lowest acculturated group $(20.1 \pm 10.1)$. The lowest acculturated group averaged with the largest disparity between Cuban and American scores.

T-tests were performed to compare the CFS and the AFS of subjects with and without diabetes. The CFS mean for subjects with NIDDM (29.2 \pm 9.1$)$ was significantly greater $(\mathrm{P}<0.001)$ than their AFS $(14.2 \pm 8.8)$. Similarly, for non-diabetic subjects, the CFS $(32.9 \pm 9.3)$ was significantly greater $(\mathrm{P}<0.001)$ than their AFS $(16.4 \pm 8.5)$. The 


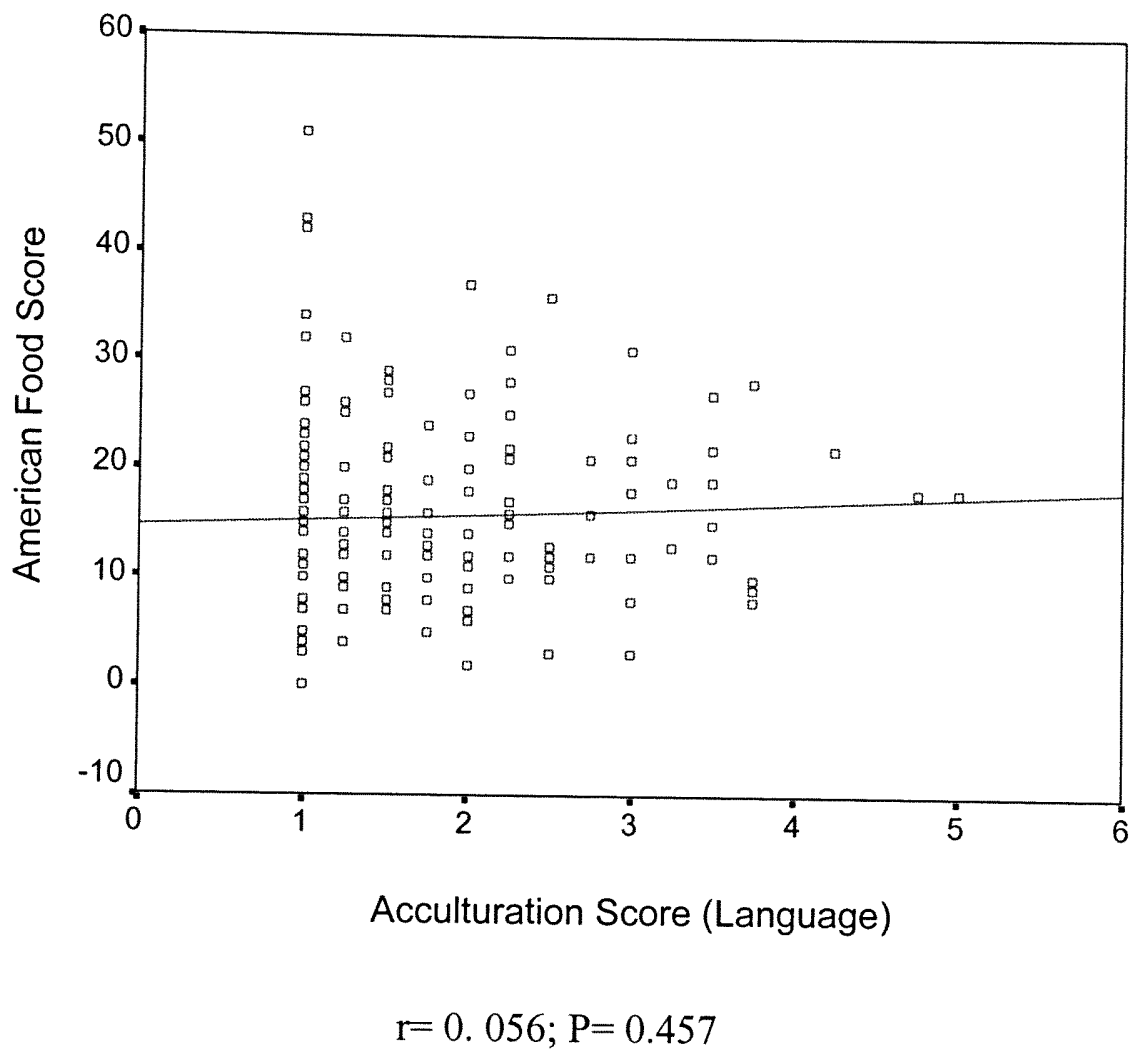

Figure 2. Correlation between the American food score and the acculturation score in all subjects $(n=178)$. 
Table 6. Comparison of Acculturation Scores with the CFS and the AFS

\begin{tabular}{|l|c|c|c|c|c|}
\hline $\begin{array}{c}\text { Language } \\
\text { Acculturation } \\
\text { level }\end{array}$ & $\mathbf{N}$ & $\begin{array}{c}\text { Cuban } \\
\text { Food Score } \\
\text { Mean } \pm \text { SD }\end{array}$ & $\begin{array}{c}\text { American } \\
\text { Food Score } \\
\text { Mean } \pm \text { SD }\end{array}$ & P * & $\begin{array}{c}\text { CSF-AFS** } \\
\text { Mean } \pm \text { SD }\end{array}$ \\
\hline Low $<1$ & 62 & $35.3 \pm 10.1^{\mathrm{a}}$ & $15.2 \pm 10.5^{\mathrm{c}}$ & $<.001$ & $20.1 \pm 10.1^{\mathrm{d}}$ \\
Middle 1-1.99 & 56 & $31.4 \pm 8.8^{\mathrm{ab}}$ & $15.5 \pm 6.7^{\mathrm{c}}$ & $<.001$ & $15.9 \pm 9.6^{\mathrm{e}}$ \\
High 2-5 & 60 & $28.5 \pm 7.8^{\mathrm{b}}$ & $16.4 \pm 7.9^{\mathrm{c}}$ & $<.001$ & $12.1 \pm 9.4^{\mathrm{e}}$ \\
\hline P*** & --- & $<.001$ & .748 & -- & $\leq .05$ \\
\hline Total & 178 & $31.8 \pm 9.4$ & $15.7 \pm 8.6$ & -- & $16.1 \pm 10.2$ \\
\hline
\end{tabular}

* P values for row comparison

** CSF-AFS $=$ Cuban Food Score minus American Food Score

*** $\mathrm{P}$ values for column comparison

Mean differences of food scores with different superscripts are significantly different at, $\mathrm{P} \leq 0.05$ 
CFS for subjects without diabetes $(32.9 \pm 9.3)$ was significantly higher $(\mathrm{P}<0.05)$ than for NIDDM (29.2 \pm 9.1$)$ (Table 7). However, AFS for subjects without diabetes (16.4 \pm 8.5$)$ was not significantly different from subjects with NIDDM (14.2 \pm 8.8$)$. A correlation between the acculturation score and the CSF among type 2 diabetics revealed a significant negative relationship $(r=-0.277 ; \mathrm{P}<0.05)$ (Figure 3$)$. When the same correlation was calculated for type 2 diabetics between acculturation and their AFS, no significant relationship was observed $(r=.204 ; \mathrm{P}=0.135)$. The correlation between the acculturation score and the CSF among non-diabetics showed a significant negative relationship $(\mathrm{r}=-0.372 ; \mathrm{P}<0.001)$ (Figure 4). No significant relationship was observed $(\mathrm{r}=0.007 ; \mathrm{P}=0.942)$ between the acculturation score and the AFS among non-diabetic subjects.

\section{Alcohol Consumption}

Subjects were placed into two groups: drinkers and non-drinkers. The nondrinkers were all those subjects who answered "zero drink" in questions 12 and 13, and who answered "don't drink" in question 14 of the MAS-CA. Among the drinkers $(n=86 ; 48.3 \%), 40.7 \%$ were drinking more after migrating, $29.1 \%$ were drinking the same amount, and $30.2 \%$ were drinking less. Among drinkers with Type 2 Diabetes, $30.4 \%$ stated that they were drinking more after migrating and $39.1 \%$ reported drinking less. Among non-diabetic drinkers, $44.4 \%$ reported drinking more and $30.2 \%$ reported drinking less. Table 4 shows subjects' alcohol consumption before and after immigration. A t-test compared the subject's alcohol consumption after migration for the type 2 diabetic subjects and the non-diabetics. The mean number of drinks per year consumed by subjects with Type 2 Diabetes $(2.73 \pm 1.32)$ was significantly less 
Table 7. Comparison of Cuban and American Food Scores for NIDDM and Nondiabetics

\begin{tabular}{|l|c|c|c|c|}
\hline & $\mathbf{N}$ & $\begin{array}{c}\text { Cuban Food Score } \\
\text { Mean } \pm \text { SD }\end{array}$ & $\begin{array}{c}\text { American Food } \\
\text { Score Mean } \pm \text { SD }\end{array}$ & P \\
\hline NIDDM* & 55 & $29.2 \pm 9.1$ & $14.2 \pm 8.8$ & $<.001$ \\
Non-diabetic & 119 & $32.9 \pm 9.3$ & $16.4 \pm 8.5$ & $<.001$ \\
\hline
\end{tabular}

* Non Insulin Dependent Diabetes Mellitus

Mean \pm SD are considered significant at $\mathrm{P}<.05$ 


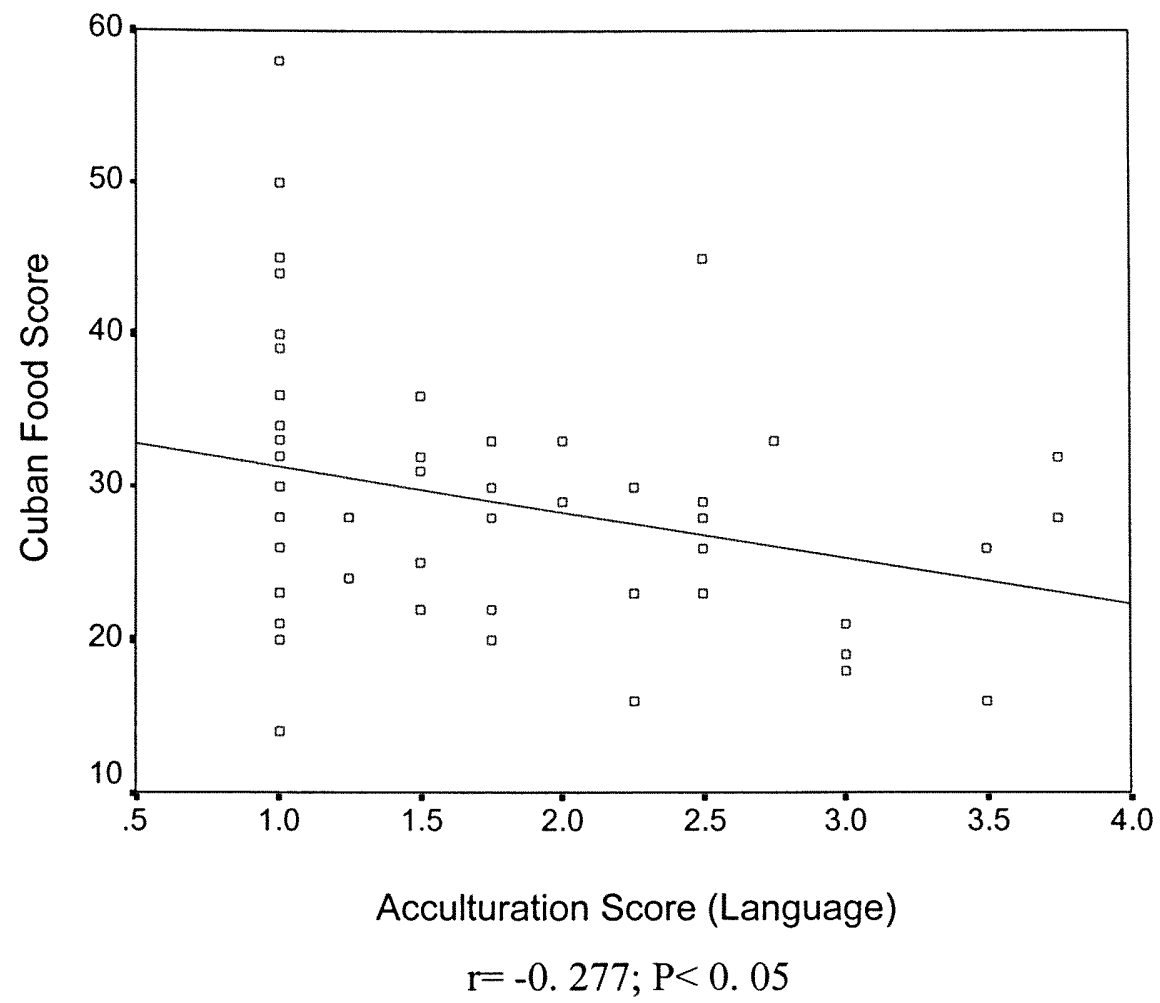

Figure 3. Correlation between the Cuban food score and the acculturation score among type 2 diabetics $(\mathrm{n}=55)$. 


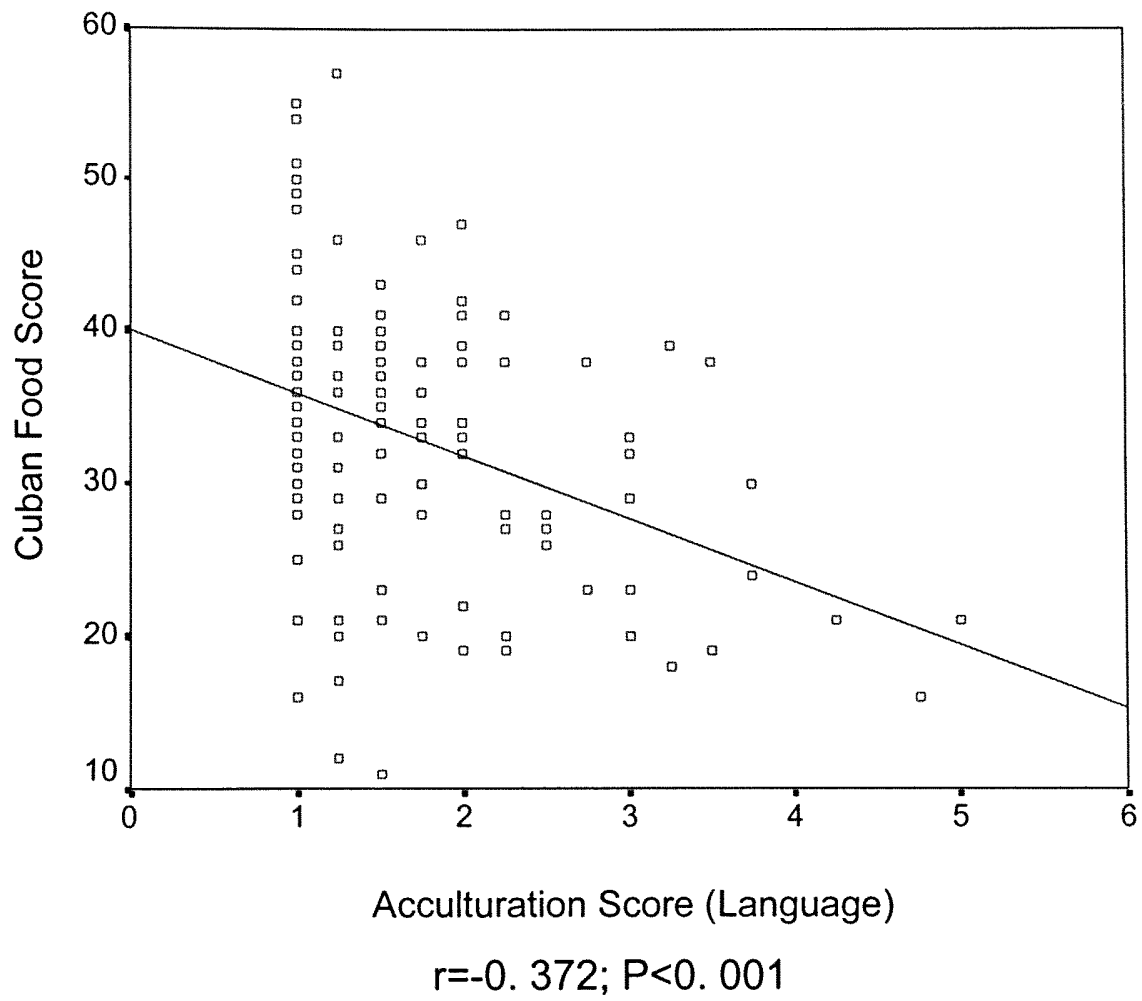

Figure 4. Correlation between the acculturation score and the Cuban food score among non-diabetics. 
$(\mathrm{P}<0.05)$ than the mean number of drinks consumed by non-diabetic subjects $(3.58 \pm$ $0.95)$.

\section{Length of Stay, Acculturation and Diet}

Subjects' length of stay was stratified into three subgroups based on how long they had lived in the USA: less than 5 years; 6-10 years; and 11 years or more, (Table 8). An ANOVA test performed on acculturation scores by length of stay in the USA was significant $(\mathrm{P}<0.05)$. Tukey's post hoc test was carried out to determine which subgroups differed. The mean acculturation score of those who lived the longest time in the USA $(1.8 \pm 0.9)$ was significantly higher $(\mathrm{P}<0.05)$ than that of the subjects who lived the shortest time in the USA $(<5$ years) $(1.3 \pm 0.4)$. However, for all lengths of stay categories, the mean acculturation scores were low, (less than two) indicating they used more Spanish than English on average. The comparison of food scores by length of stay in the USA did not show statistical significance. 
Table 8. Comparison of Acculturation Scores and Diet by Length of Stay in the USA

\begin{tabular}{|c|c|c|c|c|}
\hline $\begin{array}{c}\text { Length of } \\
\text { Stay Years }\end{array}$ & $\mathbf{N}$ & $\begin{array}{c}\text { Language } \\
\text { Acculturation } \\
\text { Scores Mean } \pm \text { SD }\end{array}$ & $\begin{array}{c}\text { Cuban Food Score } \\
\text { Mean } \pm \text { SD }\end{array}$ & $\begin{array}{c}\text { American Food } \\
\text { Score } \\
\text { Mean } \pm \text { SD }\end{array}$ \\
\hline$<5$ & 21 & $1.3 \pm 0.4^{\mathrm{a}}$ & $32.9 \pm 11.9^{\mathrm{c}}$ & $11.8 \pm 7.3^{\mathrm{d}}$ \\
$6-10$ & 18 & $1.4 \pm 0.5^{\mathrm{a}}$ & $36.6 \pm 7.7^{\mathrm{c}}$ & $15.9 \pm 9.1^{\mathrm{d}}$ \\
$\geq 11$ & 138 & $1.8 \pm 0.9$ & $31.0 \pm 9.0^{\mathrm{c}}$ & $16.2 \pm 8.6^{\mathrm{d}}$ \\
\hline
\end{tabular}

Means with different superscripts within a column are significantly different, $\mathrm{P}$ $<0.05$ 


\section{DISCUSSION}

A Multidimensional Acculturation Scale for Cuban Americans was developed (MAS-CA), which involved a series of steps. First, various measurable behaviors indicating a person's acculturation levels were identified from the literature. Among them were language usesage and preference (English / Spanish), length of stay in USA, socioeconomic status, and dietary patterns. Because of the impact that diet has on health and disease, there was a need for research on acculturation in association with dietary patterns (Bermúdez et al., 2000; Gardner et al., 1995; Gwynn et al., 1993, and Lee et al., 1999b). Specific information on qualitative aspects of the Hispanic diet such as context of the diet, factors that promote changes in food choices, and food preparation methods were lacking in the literature. Consumption of Hispanic foods, changes in dietary practices after migration, and association of the dietary practices with the level of acculturation needed further research (Gardener et al., 1995).

Secondly, the population of this study was composed of first generation Cuban Americans. Cuban Americans represent the fourth largest Hispanic American subgroup (National Institute of Health, National Institute of Health and Kidney Disease, 1997) in the USA. Unfortunately, no study in the literature developed a list of foods that can be identified solely as Cuban foods. The present study enabled the development of a list including 33 traditional Cuban food items identified and consumed by Cuban respondents.

Thirdly, the Dietary Bidimensional Acculturation Scale (D-BAS) developed for this study had two different food frequency tables. One table pertained to Cuban foods and the other to American foods. The purpose of the two food frequency tables was to 
obtain a Cuban and an American food score based on preferences of the subjects for comparison. Foods that are consumed in Cuba that may also be part of the USA diet were eliminated from the food frequency tables. This was done in order to isolate traditional Cuban foods from those found in the USA diet. This then resulted in two food frequency tables with no overlapping foods (13 food items in each). The information on the food frequency tables provided us with Cuban foods mostly consumed in Cuba that were not part of the common American dietary pattern, and the types of foods consumed mostly by the subjects, whether Cuban or American. An open-ended question included in the MAS-CA was designed to address the validity concerning the Cuban foods were included in the D-BAS. The answers to this question confirmed that the 13 Cuban foods, which were included in the Cuban food scale, were truly traditional Cuban food items. Furthermore, a pilot study and a focus group conducted prior to the study validated the content of the instruments. Thus, we believe that this instrument was able to measure the subjects' dietary acculturation.

Sample Collection

We started by selecting strategic locations mostly visited by Cuban American adults. These were all in the Miami area and included Publix Super Market, Food Start Super Market \# 3, a physician's office, an outpatient diabetic clinic, and Pan American Hospital. Difficulties encountered while trying to collect data were: (1) fear of giving personal information, time constraint of the subjects, and no interest in the study. One hundred seventy-eight subjects successfully completed the questionnaire (MAS-CA). Although the number of diabetic subjects in this study was limited $(n=57$ or $32 \%)$, results were informative. 
The acculturation score was based on four questions from the Short Acculturation Scale for Hispanic Youth (SASH-Y) developed by Barona and Miller (1994), which included language use and preference. These questions have been successfully used in previous acculturation scales (Barona \& Miller). The acculturation score was constructed as the mean of these four questions that were based on language variables ranging from one (using only Spanish) to five (using only English). A higher acculturation score indicated a higher level of acculturation towards the American culture. The mean acculturation score among all respondents was $1.7 \pm 0.85$, which indicated that the majority of the subjects were Spanish speaking and were not acculturated in terms of language. This was similar to the results reported by Bermúdez et al., 2000. The relationship between acculturation and the subjects' length of stay showed that subjects who lived in the USA longer spoke more English and had a higher acculturation score compared to those who had lived in the USA for a shorter period of time. However, those who lived eleven years or more in the USA still had an overall low acculturation score, $(1.8 \pm 0.9)$. The relationship between length of stay and diet was also studied; however, no statistical significance was found.

The Cuban food score (CFS) and the American food score (AFS) were derived from the D-BAS and ranged from 0 to 65 . The higher food score indicated a greater preference for either Cuban or the American foods. Although subjects reported having some American food intake, the overall mean CFS was significantly higher than the mean AFS. This suggests that the population of Cuban Americans included in this study preferred Cuban foods to American foods. However, when the acculturation level increased and they spent more time in the USA, the Cuban food consumption decreased, 
but American food consumption did not increase. Thus, although losses took place on one cultural domain, this did not imply gains were made on the other cultural domain. As opposed to most acculturation-related nutrition studies, which typically assume that both acculturation and dietary change follow a unidimensional-acculturation process, the DBAS was designed to measure food preferences for the two cultures involved (Lee et al., 1999b). Moreover, the subjects in this study included other ethnic foods (other than American) in their diets. Subjects were asked about the type of restaurants they frequented, $18 \%$ ate at American style restaurants, $57 \%$ ate at Cuban style restaurants, and $25 \%$ ate at other types of restaurants. This shows that Cuban Americans are eating foods from other ethnic groups other than American. This may be due to the fact that the study was conducted in Miami-Dade County (FL), which is a multicultural city with diverse Caribbean and other cultures. The MAS-CA showed that even though language may be the primary indicator for the subjects' acculturation level, it is not the only one. The results indicated that language acculturation has an inverse relationship to diet acculturation. When acculturation increases, consumption of native foods decreases. Diet and food preferences can also be used as a measure of acculturation, either singularly or with a combination of other measures.

Bermúdez et.al. (2000), who explored the relationship between acculturation, ethnicity, length of residence in the USA, and macronutrient intake, used a modified version of the acculturation scale of Cuellar et al. (1980). This scale was based on the use of English, Spanish or English and Spanish for speaking, reading or writing. Its acculturation score was based on the mean of these three language variables. Gardner et al. (1995) also studied the relationship between diet and acculturation. The acculturation 
scale used was composed of 17 questions pertaining to Hispanic versus American selfclassification as well as preference for language, movies, television, radio, friends, and foods. However, the dietary (food) variable was not extensively discussed. Lee et al. (1999b), measured dietary acculturation with a self-administered food frequency questionnaire (FFQ). The FFQ was composed of three groups of foods: (1) "common foods" or foods that are consumed frequently in both Korea and America, (2) "American foods," foods usually consumed in America but rarely consumed in Korea, and (3) "Korean foods," which were foods consumed frequently in Korea but rarely in America. Romero-Gwynn et al. (1993) collected data based on demographic characteristics, food preparation practices, and the frequency of consumption of 128 traditional Mexican foods and dishes commonly found in the typical American diet, but did not include a specific acculturation scale. They developed two lists of foods utilizing the data. The first list was based on changes in food consumption over time and indicated the foods that decreased in consumption. The second list was based on changes in food consumption over time and indicated the foods that had increased in consumption. This allowed them to divise a scale based on the dietary acculturation among Latinos of Mexican descent. The D-BAS developed for our study was the new scale designed to measure dietary acculturation. The D-BAS, which is part of the MAS-CA, followed the same rationale as that Lee et al. (1999b). The MAS-CA had both cultural domains, Cuban and American, and contained the diet variable while correlating with language, the preferred construct to measure acculturation (Barona \& Miller, 1994; Gardner et al., 1995; Gómez, 1990; Khan et al., 1997; Marín \& Gamba, 1996; Negy \& Woods, 1992; Pawson et al., 1991; Solis et al., 1990). 
The presence of diabetes and the relationship between diet and acculturation were also studied. The results showed that regardless of the presence or absence of diabetes, Cuban Americans preferred to eat Cuban foods rather than American foods. Similarly to the whole sample, as Cuban Americans with diabetes (especially those with NIDDM) became acculturated, they reduced their consumption of Cuban foods, but did not change their consumption of American foods.

The first hypothesis in our study stated that exclusion of Cuban foods and the inclusion of American foods in the diets of Cuban Americans are associated with higher levels of acculturation. Therefore, Cuban Americans who are mainly Spanish speakers would consume a higher amount of Cuban foods. This hypothesis was partially accepted because it was supported by the relationship between Cuban foods and language, as measured in the MAS-CA but, not by the relationship between American foods and language. A significant $(\mathrm{P}<0.001)$ negative relationship was found between the acculturation level and the CFS (Figure 1). However, there was not a significant correlation between acculturation level and the AFS $(\mathrm{P}=0.475)$.

The second hypothesis, which stated that Cuban Americans with Type 2 Diabetes would consume more American foods than those without diabetes, was not supported by the data. However, the subjects without diabetes ate significantly more Cuban foods than the NIDDM subjects. Perhaps, NIDDM subjects are eating American foods that were not included on the list and/or foods from other ethnic groups.

The third hypothesis, which stated that having Type 2 Diabetes would negatively influence Cuban Americans' alcohol consumption was accepted. Results suggested that having Type 2 Diabetes negatively influenced alcohol consumption among the study 
population (Table 3$)$. Type 2 diabetic subjects reported significantly $(\mathrm{P}<0.05)$ less consumption of alcohol than their non-diabetic counterparts.

Adding to the complexity of the relationship between diet and acculturation, there was a significant relationship between the subjects' length of stay and language (acculturation score). The data suggested that the more time subjects spent in the United States, specifically more than 11 years, the more acculturated they became or the more English they spoke. This is concurrent with previous acculturation studies, that is, as the length of stay or generation level increases, so does the level of acculturation (Barona \& Miller, 1994; Gardner et al., 1995; Gómez, 1990; Khan et al., 1997; Marín \& Gamba, 1996; Negy \& Woods, 1992; Pawson et al., 1991; Solis et al., 1990).

Moreover, the data showed that the diet eaten in Cuba before migration included a variety of foods. A listing of the top 33 Cuban foods mostly consumed by the subjects in Miami was developed (Table 5). Among the most commonly consumed Cuban foods were stewed legumes $(66 \%)$, cooked white rice $(65 \%)$, and boiled starchy vegetables (40\%). However, what seems to make the difference between the Cuban diet and the diets from other ethnic groups (including other Hispanic groups) was the method of food preparation. Therefore, a description for each of these foods was included in Table 5 in an attempt that this could be used by future studies with the Cuban population.

\section{Limitations}

A limitation of this study was the question that pertained to alcohol consumption which did not allow us to determine if the lack of alcohol consumption indicated in the subjects' response was due to their age or their preference. They may have indicated a lack of alcohol consumption prior to migration due to their youth, which would have 
produced inaccurate data. The questionnaire did not include a space for the subjects to provide their reason for not drinking.

\section{Conclusions}

Although more complex multidimensional acculturation scales need to be developed in regard to Hispanic acculturation, the MAS-CA proved to be a useful instrument to measure various acculturative domains. This instrument can be used with different ethnic groups by changing the foods included in the D-BAS for the population under study and also by changing the ethnic group of the remaining questions. The MAS-CA successfully showed that dietary acculturation can be quantitatively measured and that as well as language, diet can also be used in the measurement of acculturation. Health professionals can use this information to establish relationships between diet and the onset or progression of chronic diseases among Hispanic immigrants.

\section{Recommendations for Future Research}

Future research is needed in order to provide more data regarding specific postmigration dietary changes and the contribution of traditional Cuban foods as well as other Hispanic foods to current intake patterns. Researchers should also address why immigrants are changing their dietary habits. There is a need for studies that explore the relationship of immigrants' changes in dietary patterns and their health status before and after immigration. Such data will facilitate a better understanding of the relationship between health, chronic diseases (for example, diabetes, cardio-vascular diseases, cancer) 
and diet among Hispanics, which is the second-fastest growing and largest minority group living in the USA (Chávez et al., 1994). 


\section{REFERENCES}

1. Aldrich, L. \& Variyam, J.N. (2000). Acculturation erodes the diet quality of U.S. Hispanics. Food Review,23,51-55.

2. Angel, R. Guaenaccia, P.J. (1989). Mind, body, and culture: Somatization among Hispanics. Social Science Medicine, 28, 1229-1238.

3. Barona, A. \& Miller, J.A. (1994). Short acculturation scale for Hispanic youth (SASH-Y): A preliminary report. Hispanic Journal of Behavioral Sciences, 16, 155162.

4. Bermúdez, O.I., Falcón, L.M., \& Tucker, K.L. (2000). Intake and food sources of macronutrients among older Hispanic adults: Association with ethnicity, acculturation, and length of residence in the United States. Journal of the American Dietetic Association, 100, 665-673.

5. Berry, J.W. (1980). Acculturation as varieties of adaptation. In: A.M. Padilla (Ed.), Acculturation: Theory, models, and some new findings. (9-25). Boulder, CO:

Westview.

6. Birman, D. (1998). Biculturalism and perceived competence of Latino immigrant adolescents. American Journal of Community Psychology, 26, 335-355.

7. Bonnie, L. (1999). The changing American diet. Nutrition Action Health letter,26, 28.

8. Bowman, S.A., Lino, M., Gerrior, S.A., \& Basiotis, P.P. (1998). The Healthy Eating Index: 1994-96. US Dept of Agriculture, Center for Nutrition Policy and Promotion. Washington, DC.

9. Chávez, N., Sha, L., Persky, V., Langenberg, P., \& Pestano-Binghay, E. (1994). Effect of length of U.S. residence on food group intake in Mexican and Puerto Rican women. Journal of Nutrition Education, 26, 79-86.

10. Committee on Diet and Health, Food and Nutrition Board, Commission on Life Sciences, National Research Council (F\&NB, CLS/NRC). (1989). Diet and health: Implications for reducing chronic disease risk. [Abstract of Executive Summary]. Nutrition Today, March/April,36-38.

11. Cortéz DE, Rogler LH. (1994).Biculturality among Puerto Ricans adults in the United States. American Journal of Psychology,22, 707-721.

12. Council of Scientific Affairs. (1991). Hispanic health in the United States. Journal of the American Medical Association, 265, 248-252. 
13. Cuellar, I., Harris, L., \& Jasso, R. (1980). An acculturation scale for Mexican American normal and clinical populations. Hispanic Journal of Behavioral Sciences, $\underline{2}, 199-217$.

14. Dana, R.H. (1996). Assessment of acculturation in Hispanic populations. Hispanic Journal of Behavioral Sciences, 18, 317-328.

15. National Institute of Health, National Institute of Diabetes and Digestive Kidney Disease. (1995). Diabetes in America, 2 nd edition (NIH Publication 95-1468). Bethesda, MD

16. National Institute of Health, National Institute of Diabetes and Digestive Kidney Disease. (1997). Diabetes in Hispanic Americans (NIH Publication 97-3266). Bethesda, MD

17. Flegal, K.M., Ezzati, T.M., Harris, M.I, Haynes, S.G., Juarez, R.Z., Knowler, W.C., Perez-Stable, E.J., \& Stern, M.P. (1991). Prevalence of Diabetes in Mexican Americans, Cubans, and Puerto Ricans from the Hispanic Health and Nutrition Examination Survey, 1982-1984. Diabetes Care,14 (Suppl.3), 628-638.

18. Frazao, E. (1996). The American diet: a costly health problem, moving toward healthier diets. Food Review, 18, 2-7.

19. Gardner, C., Winkleby, M.A., \& Viteri, F.E. (1995). Dietary intake and acculturation levels of Hispanic immigrant men: a pilot study. Hispanic Journal of Behavioral Sciences, 17, 347-361.

20. Garza, C. (1995). Diet-related diseases and other health issues. In: S. Diva (Ed.), Hispanic Foodways, Nutrition, \& Health. (198-220). Boston, Massachusetts: Allyn \& Bacon.

21. Glanz, K. \& Kolonel, L.N. (1998). Culture, religion, diet and health: challenges and opportunities. Nutrition, 14, 238-239.

22. Gómez, M.R. (1990). Biculturalism and Subjective mental health among Cuban Americans. Social Service Review, September, 375-389.

23. Gutmann, M.C. (1999). Ethnicity, alcohol, and acculturation. Social Science \& Medicene,48, 173-184.

24. Hajat, A., Lucas, J.B., \& Kington, R. (2000). Health outcomes among Hispanic subgroups: Data from the National Health Interview Survey, 1992-95. Hyattsville, Maryland: U.S. Department of Health and Human Services. Center for Disease Control and Prevention. National Center for Health Statistics. DHHD Publication No. (PHS) 2000-12500-0155 (2/00). 
25. Hamman, R.F., Marshall, J.A., Baxter, J., Kahn, L.B., Mayer, E.J., Orleans, M., Murphy, Jr., \& Lezotte, D.C. (1989). Methods and prevalence of Non-InsulinDependent Diabetes Mellitus in a biethnic Colorado population: The San Luis Valley Diabetes Study. American Journal of Epidemiology,129, 295-311.

26. Hanis, C.L., Ferrell, R.E., Barons, S.A., Aguilar, L., Garza-Ibarra, A., Tubullch, B.R., Garcia, C.A., \& Schull, W.J. (1983). Diabetes among Mexican-Americans in Starr County, Texas. American Journal of Epidemiology,118, 659-672.

27. Keefe, S.E. \& Padilla, A.M. (1987). Chicano Ethnicity, (ed.) Albuquerque, NM: University of New Mexico Press.

28. Khan, L.K., Sobal, J., \& Martotrell, R. (1997). Acculturation, socioeconomic status, and obesity in Mexican Americans, Cuban Americans, and Puerto Ricans. International Journal of Obesity,21, 91-96.

29. Lang, S. (1992). Understanding Hispanic diets. Nutrition and Health. Human Ecology [Forum/Fall],7-11.

30. Lee, S.K., Sobal, J., \& Frongillo, E.A. (1999a). Acculturation and dietary practices among Korean Americans. Journal of the American Dietetic Association,99, 10841089.

31. Lee, S.K., Sobal, J., \& Frongillo, E.A. (1999b). Acculturation, food consumption, and diet-related factors among Korean Americans, Journal of Nutrition Education,31, 321-330.

32. Marcus, E.L. \& Berry, E.M. (1998). Refusal to eat in the elderly. Nutrition Review, 56, 163-169.

33. Marín, G, \& Gamba, R.J. (1996). A new measurement of acculturation for Hispanics: The bidimensional acculturation scale for Hispanics (BAS). Hispanic Journal of Behavioral Sciences, 18, 297-316.

34. Marín, G., Posner, S.F., \& Kinyon, J.B. (1993). Alcohol expectancies among Hispanic and non-Hispanic Whites: Role of drinking status and acculturation. Hispanic Journal of Behavioral Sciences, 15, 373-381.

35. Marín, G., Sabogal, F., Marín V.B., Otero,-Sabogal, R., \& Pérez-Stable. (1987). Development of a short acculturation scale for Hispanics. Hispanic Journal of Behavioral Sciences, 9(2), 183-205. 
36. Marks, G., Garcia, M., \& Solis, J.M.(1990). III. Health risk behaviors of Hispanics in the United States: findings from HHANES, 1982-84. American Journal of Public Health, 80 (S), 20-26.

37. Mitchell, B.D., Haffner, S.M, Hazuda, H.P., Patterson, J.K., \& Stern, M.P. Diabetes and coronary heart disease risk in Mexican Americans. Annals Epidemiology,2, 101106.

38. Moreno, C. (1997). Heart disease education and prevention program targeting immigrant Latinos using focus group responses to develop effective interventions. Journal of Community Health, 22, 435-451.

39. Negy, C. \& Woods, D.J. (1992). The importance of acculturation in understanding research with Hispanic-Americans. Hispanic Journal of Behavioral Sciences, 14, 224247.

40. Pan, Y., Dixon, Z., Himburg, S., \& Huffman, F. (1999). Asian students change their eating patterns after living in the United States. Journal of the American Dietetic Association, 99 , 54-57.

41. Pawson, I.G., Martorell, R., \& Mendoza, F.E. (1991). Prevalence of overweight and obesity in US Hispanic populations. American Journal of Clinical Nutrition,53, 1522S-1528S.

42. Rewers, M., Shetterly, S.M., Baxter, J., Marshall, J.A., \& Hamman, R.F. (1992). Prevalence of coronary heart disease in subjects with normal and impaired glucose tollerance and non-insulin dependent Diabetes Mellitus in a biethnic Colorado population. American Journal of Epidemiology,153, 1321-1330.

43. Rogler, L.H., Cortéz, D.E., \& Malgady, R.G. (1991). Acculturation and mental health status among Hispanics. American Psychologist,46, 585-597.

44. Romero-Gwynn, E., Gwynn, D., Grivetti, L., McDonald, R., Stanford, G., Turner, B., West, E., \& Williamson. (1993). Dietary acculturation among Latinos of Mexican descent*. Nutrition Today, July/August, 6-12.

45. Romero-Gwynn, E., Gwynn, D., López, M.L., Turner, B., Asarian-Anderson, J., \& Daud, M. (2000). Dietary patterns and acculturation among immigrants from El Salvador. Nutrition Today,35, 233-241.

46. Sabogal, F., Marín, G., Otero-Sabogal, R., Marín, B.V., \& Pérez-Stable, E. (1987). Hispanic familism and acculturation: What changes and what doesn't? Hispanic Journal of Behavioral Sciences, $2,397-412$. 
47. Sánchez, J.I. \& Fernández, D.M. (1993). Acculturative stress among Hispanics: a bidimensional model of ethnic identification. Journal of Apply Social Psychology, 23, 654-668.

48. Sanjur, D. (1995). Hispanic Foodways, Nutrition, and Health, (ed.) Boston, Massachusetts: Allyn \& Bacon.

49. Satia, J.A., Patterson, R.E., Taylor, V.M., Cheney, C.L., Shiu-Thornton, S., Chitnarong, K., \& Kristal, A.R. (2000). Use of qualitative methods to study diet, acculturation, and health in Chinese-American women. Journal of the American Dietetic Association, 100, 934-940.

50. Schultz, J.D., Spindler, A.A., \& Josephson, R.V. (1994). Diet and acculturation in Chinese women. Journal of Nutrition Education, 26, 266-272.

51. Solis, J.M., Marks, García. M., \& Shelton, D. (1990). II. Acculturation, access to care, and use of preventive services by Hispanics: Findings from HHANES 1982-84. American Journal of Public Health.80, 11-19.

52. Sorlie, P.D., Backlund, E., Johnson, N.J., \& Rogot, E. (1993). Mortality by Hispanic status in the United States. Journal of the American Medical Association, 270, 24642468.

53. Stern, M.P., Gaskill, S.P., Hazuda, H.P., Gardner, L.I., \& Haffner, S.M. (1983). Does obesity explain excess prevalence of diabetes among Mexican Americans? Results of the San Antonio Heart Study. Diabetologia,24, 272-277.

54. Whitney, R.M. (1998). Alcohol use among Cuban-Americans, Mexican-Americans, and Puerto Ricans. Alcohol Health \& Research World, 22, 265-270. 


\section{APPENDICES}


If you:

\section{Are you from Cuba?}

Are between the ages of $40-65$ years

Would like to know more about your diet

Want to receive a free supermarket tour from a REGISTERED DIETITIAN

* Are willing to complete a questionnaire

* WE NEED YOUR HELP!!!

- Please call Frances D. Asencio for appointment: (305) 443-4598 or (305) 737-3418 (beeper)

Your information will be used for a study being conducted by Dr. F Huffman \& Frances Asencio, RD at Florida International University.

The information you provide will be kept confidential.

* Tour hours: 10:00 am-12:00 pm Wednesday \& Sunday and 4:00-6:00 pm on Saturday. 


\section{Are you from Cuba?}

If you:

Are between the ages of 40-65 years

Would you like to know more about your diet

* Want to receive free nutritional counseling from a REGISTER DIETITIAN

Are willing to complete a questionnaire

* We need your help!!

* Please call Frances D. Asencio for appointment: (305) 443-4598 or (305) 737-3418 (beeper)

* The information you provide will be kept completely confidential

- Your information will be used for a study being conducted by Dr. F Huffman \& Frances Asencio, RD at Florida International University. 


\section{¿Es usted Cubano (a)?}

Si usted tiene entre 40-65 años de edad

- Le gustaria saber mas sobre su dieta

Quisiera recibir orientacion nutricional (completamente gratis) por una Dietista Registrada

Esta dispuesto (a) a llenar un cuestionario

* iNosotros lo (la) necesitamos!

e Interesados favor llamar a Frances D. Asencio, RD:

(305) 443-4598 o al beeper (305) 737-3418

Su información completamente confidencial, será ultilizada por La Dra. F. Huffman y Frances D. Asencio, RD para un estudio de "Florida International University". 


\section{¿Es usted Cubano (a)?}

- Si usted tiene entre 40 y 65 años de edad

- Le gustaría conocer más sobre su dieta

- Quisiera que una Dietista Registrada le diera un "tour" por el supermercado IGRATIS!

Esta dispuesto (a) a llenar un questionario

- iNosotros lo (la) necesitamos!

Interesados favor llamar a Frances D. Asencio, RD:

(305) 443-4598 o al beeper (305) 737-3418

La Dra. F. Huffman y Frances D. Asencio, RD utilizarán su información (completamente confidencial) para un estudio de "Florida International University".

Horario del "tour" Lunes 6:00-8:00 pm, Miércoles 4:00-6:00 pm y Domingos 3:00-6:00 pm 


\section{$\underline{\text { Appendix B }}$}

\section{INFORMED CONSENT}

DIETARY CHANGES AMONG NON-DIABETIC AND TYPE II DIABETIC CUBAN AMERICAN-IMMIGRANTS, AS A MEASURE OF ACCULTURATION.

I freely and voluntarily consent to be a participant in the research project entitled: DIETARY CHANGES AMONG NON-DIABETIC AND TYPE II DIABETIC CUBAN AMERICAN-IMMIGRANTS, AS A MEASURE OF ACCULTURATION with Frances D. Asencio RD and Dr. F. Huffman as investigators.

I understand that the purpose of this research is to explore diets of Cuban American and diet changes they make because they live in the United States.

I understand that I will be answering 40 questions in order to provide information about my diet, demographics, social behavior, and psychological aspects. I understand that answering the questionnaire would take approximately 10 minutes. I also understand that there are no anticipated risks involved in my participation in this study. The benefit will be to receive a store tour by one of the investigators, which will help me better select food items and improve my nutrition knowledge. I have been told that my responses will be kept strictly confidential. Only a code number will identify the questionnaire scores, and my individual performance will not be revealed to anyone. The signed consent forms will be kept separate from the questionnaires in a locked cabinet.

I have been given the right to ask questions concerning the procedure and all questions have been answered to my satisfaction. I understand that if I desire further 
information about this research I should contact Dr. F. Huffman at (305) 348- 3788. I have been offered a copy of this informed consent form.

I understand that I can stop my participation at any time.

I have read and I understand the above.

Participant's signature

Date

I have explained and defined in detail the research procedure in which the participant has agreed to take part and have offered him/her a copy of this informed consent form.

Frances D. Asencio RD

Fatma G. Huffman Ph.D., RD

Date

Investigators' signatures 
Consentimiento

CAMBIOS DIETETICOS ENTRE INMIGRANTES CUBANOS NO DIABETICOS E INMIGRANTES CUBANOS CON DIABETES MELLITUS TIPO 2, COMO MEDIDA DE ACULTURALIZACION

Yo libre y voluntariamente consiento a participar en el proyecto titulado: CAMBIOS DIETETICOS ENTRE INMIGRANTES CUBANOS NO DIABETICOS E INMIGRANTES CUBANOS CON DIABETES MELLITUS TIPO 2, COMO MEDIDA DE ACULTURALIZACION, con Frances D. Asencio RD y Fatma Huffman Ph.D., RD como investigadoras.

Yo entiendo que el propósito de este estudio es explorar las dietas de los CubanoAmericanos y los cambios dietarios que se dan a consecuencia de vivir en los Estados Unidos.

Yo entiendo que solamente tendré que contestar 40 preguntas relacionadas a mi dieta, aspectos sociodemográficos y psicosociales, entiendo que llenar el cuestionario tomará aproximadamente 10 minutos. También entiendo que con mí participación en este estudio no hay riesgos anticipados. Con mí participación en este estudio obtendré un recorrido por el Supermercado el cual será ofrecido por unas de las investigadoras. Dicho recorrido me ayudará a hacer una mejor selección de alimentos y a aumentar mís conocimientos sobre nutrición. Me fué dicho que mis respuestas se mantendrán estrictamente confidenciales. Los resultados del cuestionario serán solamente identificados con un código numérico y a demás mí desempeño no se le divulgará a nadie. Las hojas de consentimento se mantendrán separadas de los cuestionarios en un gabinete cerrado. 
Se me ha dado el derecho a hacer preguntas relacionadas al procedimiento y todas las preguntas me fuerón contestadas satisfactoriamente. Entiendo que de yo desear información adicional respecto al estudio, debería llamar a la Dra. Fatma Huffman al (305) 348-3788. Se me ofreció una copia de esta hoja de consentimiento.

Yo entiendo que yo puedo detener mi participación de esta investigación en culaquier momento.

Yo leí y entiendí lo antes mencionado.

Firma del participante

Fecha

Yo expliqué y definíen detalles el procedimiento del estudio en el cual el participante acordó tomar parte. Yo le ofrecí a él (ella) una copia de esta hoja de consentimiento.

Frances D. Asencio RD

Fatma G. Huffman Ph.D., RD

Fecha

Frima de las investigadoras 


\title{
FLORIDA INTERNATIONAL UNIVERSITY \\ College of Health and Urban Affairs
}

\author{
Frances D. Asencio, R.D. \\ 4460 SW $3^{\text {rd }}$ Street \\ Miami, FL 33134
}

July 17,2000

Dear Ms. Asencio:

Your IRB application has been reviewed and your study design has been found satisfactory. One copy of your application with my signature of approval is returned to you.

After receiving IRB approval, there are additional reporting requirements. Federal regulations require that the researcher submit yearly reports to the Chair of the IRB. If you complete your study within less than one year, you will submit a final report.

A yearly report or final report indicates:

1) Minor changes in the protocol for treating human subjects. (Major changes cannot be made without approval of the IRB).

2) Difficulties with any human subjects that occurred during the Year. If major difficulties occur with any human subjects, the IRB must be notified immediately.

3) Any other matters related to the human subjects used in the Study.

Please send your report to

Prof. B. Gerstman

Chairman, University Research Council

Department of Physics

CP 204.

Good luck with your study!

Sincerely,

Marie-Luise Friedemann, RN, PhD

Research Director 


\section{Appendix D}

\section{Multidimensional Acculturation Scale for Cuban Americans}

\section{Dietary Bidimensional Acculturation Scale}

Age:

Gender:

Are you dieting? Yes / No

Are you diabetic? No / Yes (NIDDM or IDDM)

1. Instructions: For each food item indicate with a check mark the category that best describes the frequency with which you usually eat that particular food item. Table A

\begin{tabular}{|c|c|c|c|c|c|c|c|}
\hline Food Item & Quantity & $\begin{array}{l}1 \text { or } \\
\text { more } \\
\text { per day }\end{array}$ & $\begin{array}{l}3-6 \\
\text { per } \\
\text { week }\end{array}$ & $\begin{array}{l}1-2 \\
\text { per } \\
\text { week }\end{array}$ & $\begin{array}{l}2 \text { per } \\
\text { month }\end{array}$ & $\begin{array}{l}1 \text { per } \\
\text { month }\end{array}$ & Never \\
\hline Cuban bread & 1 slice & & & & & & \\
\hline Mango & \begin{tabular}{|l|}
1 \\
medium
\end{tabular} & & & & & & \\
\hline Cuban coffee & 1 & & & & & & \\
\hline $\begin{array}{l}\text { Boiled starchy } \\
\text { vegetables }\end{array}$ & $1 / 2$ cup & & & & & & \\
\hline $\begin{array}{l}\text { Stewed black } \\
\text { beans }\end{array}$ & $1 / 2$ cup & & & & & & \\
\hline Cooked rice & $1 / 2$ cup & & & & & & \\
\hline $\begin{array}{l}\text { Fried ripe } \\
\text { plantain }\end{array}$ & 2 pieces & & & & & & \\
\hline $\begin{array}{l}\text { Fried green } \\
\text { plantain }\end{array}$ & 2 pieces & & & & & & \\
\hline $\begin{array}{l}\text { Fried pork } \\
\text { chunks }\end{array}$ & $3 \mathrm{oz}$ & & & & & & \\
\hline $\begin{array}{l}\text { Fried/breaded } \\
\text { fish }\end{array}$ & $3 \mathrm{oz}$ & & & & & & \\
\hline $\begin{array}{l}\text { Boiled meat } \\
\text { with } \\
\text { vegetables } \\
\text { "ajiaco" }\end{array}$ & 1 cup & & & & & & \\
\hline Chicken soup & 1 cup & & & & & & \\
\hline Flan & $\begin{array}{l}1 / 2 \text { cup or } \\
1 / 8\end{array}$ & & & & & & \\
\hline & & 5 & 4 & 3 & 2 & 1 & 0 \\
\hline
\end{tabular}


Table B

\begin{tabular}{|c|c|c|c|c|c|c|c|}
\hline $\begin{array}{l}\text { Food } \\
\text { Item }\end{array}$ & Quantity & $\begin{array}{l}1 \text { or } \\
\text { more per } \\
\text { day }\end{array}$ & $\begin{array}{l}3-6 \text { per } \\
\text { week }\end{array}$ & $\begin{array}{l}1-2 \text { per } \\
\text { week }\end{array}$ & $\begin{array}{l}2 \text { per } \\
\text { month }\end{array}$ & $\begin{array}{l}1 \text { per } \\
\text { month }\end{array}$ & Never \\
\hline $\begin{array}{l}\text { Cheese- } \\
\text { cake }\end{array}$ & $1 / 8$ & & & & & & \\
\hline $\begin{array}{l}\text { Corn- } \\
\text { flakes }\end{array}$ & $1 \mathrm{oz}$ & & & & & & \\
\hline $\begin{array}{l}\text { Bagel with } \\
\text { cream } \\
\text { cheese }\end{array}$ & 1 & & & & & & \\
\hline $\begin{array}{l}\text { Potato } \\
\text { chips }\end{array}$ & $1 \mathrm{oz}$ bag & & & & & & \\
\hline TV dinner & 1 & & & & & & \\
\hline $\begin{array}{l}\text { Chicken } \\
\text { nuggets }\end{array}$ & 3 pieces & & & & & & \\
\hline $\begin{array}{l}\text { Tuna } \\
\text { salad }\end{array}$ & $1 / 2$ cup & & & & & & \\
\hline "Tacos" & 1 & & & & & & \\
\hline Apple pie & $1 / 8$ & & & & & & \\
\hline $\begin{array}{l}\text { Frozen } \\
\text { yogurt }\end{array}$ & 1 cup & & & & & & \\
\hline Broccoli & $1 / 2$ cup & & & & & & \\
\hline Margarine & $\begin{array}{l}1 \text { tea- } \\
\text { spoon }\end{array}$ & & & & & & \\
\hline $\begin{array}{l}\text { Gravy/ } \\
\text { dressing }\end{array}$ & $\begin{array}{l}\text { 1table- } \\
\text { spoon }\end{array}$ & & & & & & \\
\hline & & 5 & 4 & 3 & 2 & 1 & 0 \\
\hline
\end{tabular}


11. Instructions: Circle the letter below each question that best answers the question of you.

A. Demographic and social behavior

1. Where were you born?

a) USA Please specify parent's origins

b) Cuba Please specify parent's origins

c) Other specify Please specify parent's origins

2. How long have you been in the USA?

a) Less than 5 years

b) $6-10$ years

c) $11-15$ years

d) More than 15 years

3. Please indicate your status.

a) Single

b) Married - Please specify spouse nationality

c) Living with significant other - Please specify his/her nationality

4. Who are you living with?
a) Alone
b) With spouse or partner
c) With parents
d) With children
e) With other relative other than parents
f) With roommate(s)

5. Do you live in a mostly Hispanic neighborhood?
a) Yes
b) No

6. Highest-grade level completed.
a) Elementary School
b) High School
c) Associate Degree
d) Bachelor
e) Higher

7. Please indicate your gross yearly income.
a) $\$ 24,000$ or less
b) $\$ 24,000-36,000$
c) $\$ 36,000-50,000$
d) $\$ 50,000$ or higher

8. Frequency of dining out.
a) None
b) 1-2 times per week
c) 3-5 times per week
d) More than 5 times per week

9. What type of restaurant do you visit most frequently?
a) American style
b) Mexican style 
c) Cuban style

d) Other specify

10. Who cooks at your house?
a) Myself
b) Spouse
c) Mother
d) Father
e) Nobody
f) Other specify

11. What five items do you consume now that you consider being traditional?

a)

b)

c)

d)

e)

\section{B. Alcohol Consumption}

12. How much alcohol did you usually consume before immigration? One standard drink equals: one 12-ounce bottle of beer, one 5-ounce glass of wine, or 1.5 ounces of distilled spirits (NIAAA). Please check only one, indicating the category that best describes the frequency with which you used to drink.

\begin{tabular}{|l|l|l|l|}
\hline $\begin{array}{l}\text { \# of } \\
\text { drink(s) }\end{array}$ & Daily & Weekly & Yearly \\
\hline 0 & & & \\
\hline 1 & & & \\
\hline $2-3$ & & & \\
\hline$\geq 4$ & & & \\
\hline
\end{tabular}

13. How much alcohol do you consumed after immigration to the U.S.? Please check only one indicating the category that best describes the frequency with which you usually drink.

\begin{tabular}{|l|l|l|l|}
\hline $\begin{array}{l}\text { \# of } \\
\text { drink(s) }\end{array}$ & Daily & Weekly & Yearly \\
\hline 0 & & & \\
\hline 1 & & & \\
\hline $2-3$ & & & \\
\hline$\geq 4$ & & & \\
\hline
\end{tabular}

14. How much do you drink now as compared to before immigration?
a) More
b) Same
c) Less
d) Don't drink

\section{SASH-Y (Short Acculturation Scale for Hispanic Youth)}

15. What language(s) do you usually speak at home?
a) only Spanish
b) more Spanish than English
c) both equally
d) more English then Spanish
e) only English 
16. In which language do you usually think?
a) only Spanish
b) more Spanish than English
c) both equally
d) more English than Spanish
e) only English

17. What language(s) do you usually speak with your friends?
a) only Spanish
b) more Spanish than English
c) both equally
d) more English than Spanish
e) only English

18. In what language(s) are the TV/radio programs you usually listen to?
a) only Spanish
b) more Spanish than English
c) both equally
d) more English than Spanish
e) only English

\section{Psycho-social}

19. "I consider myself as an American person independently of my birth place".
a) Strongly agree
b) Agree
c) Neither agree or disagree
d) Strongly disagree
e) Disagree

20. "I consider myself a Cuban person independently of my citizenship or place I where live".
a) Strongly agree
b) Agree
c) Neither agree or disagree
d) Strongly disagree
e) Disagree

\section{Thank you!}


Escala Multidimensional de Aculturalización para Cubanos Americanos

I. Escala de Aculturalización Dietaria Bidimensional

Edad:__ Sexo: ___ ¿Esta usted a dieta? Si / No

¿Es usted diabético? $\mathrm{No} / \mathrm{Si}$ (Insulina dependiente o no-insulina dependiente)

I. Instrucciones: Para cada alimento seleccione con una marca de cotejo la categoría que mejor describe la frecuencia con que usted consume cada alimento mencionado.

Tabla A

\begin{tabular}{|c|c|c|c|c|c|c|c|}
\hline Alimento & $\begin{array}{l}\text { Canti- } \\
\text { dad }\end{array}$ & $\begin{array}{l}1 \text { ó más } \\
\text { por día }\end{array}$ & $\begin{array}{l}\text { 3-6 por } \\
\text { semana }\end{array}$ & $\begin{array}{l}\text { 1-2 por } \\
\text { semana }\end{array}$ & $\begin{array}{l}2 \text { por } \\
\text { mes }\end{array}$ & $\begin{array}{l}1 \\
\text { por } \\
\text { mes }\end{array}$ & Nunca \\
\hline Pan cubano & 1 trozo & & & & & & \\
\hline Mango & $\prod_{\text {no }}^{1}$ & & & & & & \\
\hline $\begin{array}{l}\text { Café } \\
\text { Cubano }\end{array}$ & 1 & & & & & & \\
\hline $\begin{array}{l}\text { Viandas } \\
\text { hervidas }\end{array}$ & $1 / 2$ taza & & & & & & \\
\hline $\begin{array}{l}\text { Frijoles } \\
\text { negros }\end{array}$ & $1 / 2$ taza & & & & & & \\
\hline Arroz cocido & $1 / 2$ taza & & & & & & \\
\hline $\begin{array}{l}\text { Plátano } \\
\text { maduro frito }\end{array}$ & $\begin{array}{l} \\
\text { peda- } \\
\text { zos } \\
\end{array}$ & & & & & & \\
\hline Tostones & 2 & & & & & & \\
\hline $\begin{array}{l}\text { Masitas de } \\
\text { puerco fritas }\end{array}$ & $3 \mathrm{oz}$ & & & & & & \\
\hline $\begin{array}{l}\text { Pescado } \\
\text { empani- } \\
\text { zado frito }\end{array}$ & $3 \mathrm{oz}$ & & & & & & \\
\hline Ajiaco & 1 taza & & & & & & \\
\hline $\begin{array}{l}\text { Sopa de } \\
\text { pollo }\end{array}$ & 1 taza & & & & & & \\
\hline Flan & $\begin{array}{l}1 / 2 \text { taza } \\
\text { ó } 1 / 8\end{array}$ & & & & & & \\
\hline & & 5 & 4 & 3 & 2 & 1 & 0 \\
\hline
\end{tabular}


Tabla B

\begin{tabular}{|c|c|c|c|c|c|c|c|}
\hline Alimento & $\begin{array}{l}\text { Canti- } \\
\text { dad }\end{array}$ & $\begin{array}{l}1 \text { ó más } \\
\text { por día }\end{array}$ & $\begin{array}{l}\text { 3-6 por } \\
\text { semana }\end{array}$ & $\begin{array}{l}1-2 \text { por } \\
\text { semana }\end{array}$ & $\begin{array}{l}2 \text { por } \\
\text { mes }\end{array}$ & $\begin{array}{l}1 \text { por } \\
\text { mes }\end{array}$ & Nunca \\
\hline "Cheesecake" & $1 / 8$ & & & & & & \\
\hline "Cornflakes" & $10 z$ & & & & & & \\
\hline $\begin{array}{l}\text { "Bagel con } \\
\text { queso crema" }\end{array}$ & 1 & & & & & & \\
\hline $\begin{array}{l}\text { "Chips" } \\
\text { (Doritos, } \\
\text { Ruffels, otros) }\end{array}$ & $\begin{array}{l}\text { Bolsa } \\
\text { de } 1 \\
\text { oz }\end{array}$ & & & & & & \\
\hline "TV dinner" & 1 & & & & & & \\
\hline $\begin{array}{l}\text { "Chicken } \\
\text { Nuggets" } \\
\text { Pedacitos de } \\
\text { pollo } \\
\text { empanizado }\end{array}$ & $\begin{array}{l}3 \\
\text { trozos }\end{array}$ & & & & & & \\
\hline $\begin{array}{l}\text { Ensalada de } \\
\text { "tuna" }\end{array}$ & $\begin{array}{l}1 / 2 \\
\text { taza }\end{array}$ & & & & & & \\
\hline Tacos & 1 & & & & & & \\
\hline $\begin{array}{l}\text { "Pie" de } \\
\text { manzana }\end{array}$ & $1 / 8$ & & & & & & \\
\hline Brócoli & $1 / 2$ taza & & & & & & \\
\hline Margarina & $\begin{array}{l}1 \\
\text { cucha- } \\
\text { radita }\end{array}$ & & & & & & \\
\hline $\begin{array}{l}\text { "Frozen } \\
\text { Yogurt" }\end{array}$ & 1 taza & & & & & & \\
\hline \multirow[t]{2}{*}{$\begin{array}{l}\text { "Gravy / } \\
\text { dressing" }\end{array}$} & $1 \mathrm{cda}$ & & & & & & \\
\hline & & 5 & 4 & 3 & 2 & 1 & 0 \\
\hline
\end{tabular}

2 Por favor continúe en la página 3 
II. Instrucciones: Circule la letra que mejor contesta la pregunta.

\section{A. Data demográfica y social}

1. ¿Dónde nació?
a) USA Por favor indique nacionalidad de sus padres
b) Cuba Por favor indique nacionalidad de sus padres
c) Otro especifique Por favor indique nacionalidad de sus padres

2. ¿Cuánto tiempo lleva en los Estados Unidos?
a) menos de 5 años
b) 6-10 años
c) 11-15 años
d) más de 15 años

3. Indique su estado civil
a) Soltero
b) Casado - Por favor especifique la nacionalidad de su cónyuge
c) Convivio con mi pareja - Por favor especifique la nacionalidad de su pareja

4. ¿Con quién vive?
a) Solo
b) Con mi esposo (a) o pareja
c) Con mis Padres
d) Con mi (s) hijo (s)
e) Con familiares que no son los padres
f) Con amigos (as)

5. ¿Vive usted en un vecindario mayormente Hispano?
a) $\mathrm{Si}$
b) No

6. Indique su nivel de escolaridad.
a) Escuela elemental
b) "High School"
c) Grado Asociado
d) Bachillerato
e) Superior a las anteriores

7. Favor indique su salario neto anual.
a) $\$ 24,000$ ó menos
b) $\$ 25,000-\$ 36,000$
c) $\$ 36,000-\$ 50,000$
d) $\$ 50,000$ ó mayor

8. ¿Con qué frecuencia come fuera del hogar?
a) nunca
b) 1-2 veces por semana
c) 3-5 veces por semana
d) más de 5 veces por semana 
9. ¿Qué tipo de restaurante visita más frecuentemente?
a) estilo Americano
b) estilo Mejicano
c) estilo Cubano
d) otro, especifique

10. ¿Quién cocina en su casa?
a) Yo
b) Esposo (a) o pareja
c) Mamá
d) Papá
e) Nadie
f) Otro favor especifique

11. Mencione cinco alimentos que usted consuma comúnmente los cuales considera son tradicionales.

a)

b)

c)

d)

e)

\section{B. Consumo de alcohol}

12. ¿Cuánto alcohol usted consumia antes de inmigrar? Un trago equivale a: una botella de 12 oz de cerveza, una botella de 5 oz de vino o 1.5 oz de alcohol (NIAAA). Favor marque sólo una vez indicando la categoria que mejor describe la frecuencia con que usted tomaba.

\begin{tabular}{|l|l|l|l|}
\hline $\begin{array}{l}\text { \# de } \\
\text { tragos }\end{array}$ & Diario & Semanal & Anual \\
\hline 0 & & & \\
\hline 1 & & & \\
\hline $2-3$ & & & \\
\hline$\geq 4$ & & & \\
\hline
\end{tabular}

13. ¿Cuánto alcohol consume usted después de su inmigración a este pais? Favor marque sólo una vez indicando la categoria que mejor describe la frecuencia con que usted toma.

\begin{tabular}{|l|l|l|l|}
\hline $\begin{array}{l}\text { \# de } \\
\text { tragos }\end{array}$ & Diario & Semanal & Anual \\
\hline 0 & & & \\
\hline 1 & & & \\
\hline $2-3$ & & & \\
\hline$\geq 4$ & & & \\
\hline
\end{tabular}

14. ¿Cuánto mas toma usted ahora en comparación con antes de inmigrar?
a) Mucho más
b) Igual
c) Menos
d) No tomo 
C. SASH-Y (Short Acculturation Scale for Hispanic Youth)

15. ¿Qué idioma(s) usted habla en su casa?
a) sólo Español
b) más Español que Inglés
c) ambos iguales
d) más Inglés que Español
e)sólo Inglès

16. ¿En qué idioma(s) usted usualmente piensa?
a) sólo Español
b) más Español que Inglés
c) ambos iguales
d) más Inglés que Español
e) sólo Inglés

17. ¿En qué idioma(s) usted usualmente habla con sus amistades?
a) sólo Español
b) más Español que Inglés
c) ambos iguales
d) más Inglés que Español
e)sólo Inglés

18. ¿En qué idioma(s) prefiere escuchar los programas de radio y televisión que usualmente oye?
a) sólo en Español
b) más en Español que en Inglés
c) ambos iguales
d) más en Inglés que en Español
e) sólo en Inglés

C. Psicosocial

19. "Yo me considero una persona Americana independientemente del lugar donde naci".
a) Muy de acuerdo
b) De acuerdo
c) Ni de acuerdo ni en desacuerdo
d) En desacuerdo
e) Muy en desacuerdo

20. "Yo me considero una persona Cubana independientemente de mi ciudadania o del lugar donde vivo."

a) Muy de acuerdo

b) De acuerdo

c) Ni de acuerdo ni en desacuerdo

d) En desacuerdo

e) Muy en desacuerdo

\section{¡Gracias!}

